\title{
Comments
}

\author{
RULE 60(b): SURVEY AND PROPOSAL FOR \\ GENERAL REFORM
}

This Comment analyzes the use of rule 60(b) of the Federal Rules of Civil Procedure ${ }^{1}$ and, in light of that analysis, suggests modifications to the rule. The Advisory Committee has not suggested amendments to rule $60(\mathrm{~b})$ since $1955,{ }^{2}$ and the last amendment adopted dates from $1948 .^{3}$ In its present form, rule 60(b) permits a court to relieve a party from final judgment upon his own motion made within a reasonable time not to exceed one year for

(1) mistake, inadvertence, surprise, or excusable neglect; (2) newly discovered evidence which by due diligence could not have been discovered in time to move for a new trial ... [and] (3) fraud (whether heretofore denominated intrinsic or extrinsic), misrepresentation, or other misconduct of an adverse party . . . .

1. Fed. R. Crv. P. 60 (b):

On motion and upon such terms as are just, the court may relieve a party or his legal representative from a final judgment, order, or proceeding for the following reasons: (1) mistake, madvertence, surprise, or excusable neglect; (2) newly discovered evidence which by due diligence could not have been discovered in time to move for a new trial under Rule $59(\mathrm{~b})$; (3) fraud (whether heretofore denominated intrinsic or extrinsic), misrepresentation, or other misconduct of an adverse party; ... or (6) any other reason justifying relief from the operation of the judginent. The motion slall be made within a reasonable time, and for reasons (1), (2), and (3) not more than one year after the judgment, order, or proceeding was entered or taken.... This rule does not limit the power of a court to entertain an imdependent action to relieve a party from a judgment, order, or proceeding, or to grant relief to a defendant not actually personally notified as provided in Title 28 , U.S.C., $\S 1655$, or to set aside a judgment for fraud upon the court. Writs of coram nobis, coram vobis, audita querela, and bills of review and bills in the nature of a bill of review, are abolished, and the procedure for obtaining any relief from a judgment sliall be by motion as prescribed in these rules or by an independent action.

2. Report of Proposed Amendments to the Rules of Civil Procedure for THe UnITEd States District CourTs 61-63 (1955) [heremafter cited as 1955 DrafT].

3. Report of Proposed Amendments to Rules of Crvil Procedure for the District COURTS OF THE UNITED StaTES 78-84 (1946) [hereinafter cited as 1946 Draft]; see Second Prelminary Draft of Proposed Amendments to Rules of Civil Procedure for the District Courts of the United States 69-74 (1945) [hereinafter cited as 1945 DRAFT]. The annendment was adopted December 27, 1946, and became effective Marcli 19, 1948. Fed. R. Crv. P. 86(b). The amendment of December 29, 1948, effective October 20, 1949, FED. R. Crv. P. 86(c), reflected a technical change in the designation of a statute. 
In addition, the rule permits relief for "any other reason justifying relief" subject only to the requirement that the motion be made "within a reasonable time," and for "fraud upon the court" without any time limit. Finally, the rule preserves the previously developed independent action for relief witlout express time restriction.

Parties have sought to evade the time limits under subdivisions (1)-(3) by independent action rather than a 60(b) motion or by relying on grounds of "fraud upon the court" or "any other reason." The federal courts' response to such attempts has been varied and has created significant confusion in three main areas. First, there is considerable doubt whether the extrinsic-intrinsic distinction that was abrogated in subdivision (3) motions survives in "any other reason" motions and in independent actions grounded upon fraud. Second, it is unclear whether a claim falling within the first three subdivisions precludes relief on the same facts under the "any other reason" clause. Third, the federal courts have failed to achieve a consensus on how "fraud upon the court" differs from other kinds of fraud.

This Comment argues that the extrinsic-intrinsic fraud distinction is illusory and unjustified as used by the federal courts and should be abandoned; that the relationship between the "any other reason" clause and the other clauses stating grounds for relief will never be clarified as long as the strict one-year time limitation applies to the latter clauses while only an equitable limitation applies to the former; and that relief for "fraud upon the court" should depend upon principles different from those underlying relief for other kinds of fraud and must rest on equitable considerations rather than mechamical tests.

Part I explores the relevant history of rule $60(\mathrm{~b})$ and its contribution to the rule's present problems. Part II examines in particular the problems of those who seek relief from fraud. Part III analyzes problems presented by the "any other reason" clause and its relationship to the first three subdivisions. Finally, part IV outlines prerequisites for any successful amendment and proposes modifications of the present rule. ${ }^{4}$

4. This Comment excludes from consideration problems concerning relief from judicial error [see generally $7 \mathrm{~J}$. MOORE, FEDERAL PRACTICE TT 60.15(7), 60.22(3) (2d ed. 1970) [hereinafter referred to as Moore]; Comment, Federal Rule 60(b): Finality of Civil Judgments v. Self-Correction by District Court of Judicial Error of Law, 43 Notre DAME LAw. 98 (1967)], who is a "party" for purposes of relief [see generally Comment, Use of Rule 60(b) to Vacate Federal Denaturalization Decree, 10 STAN. L. REv. 767 (1958)], and the requirement of appellate court leave before granting relief [see 1955 Draft 61-62; Prelimtnary Draft of Proposed Amendments to Rules of Civil Procedure for the UNITEd States District CourTs 56 (1954) thereinafter referred to as 1954 Drafr]; Note, Federal Rules 52(a) and 60(b)-A Chinese Puzzle, 21 Sw. L.J. 339, 344-46 (1967); 7 MOORE \ा 60.30, at 330-40 \& n.25]. 


\section{The Problem Generally}

Rule 60 (b) is an attempt to reconcile the values of finality and doing individual justice. ${ }^{5}$ Generally, finality precludes relief from a judgment, other than timely appellate relief, as to "a right, question or fact [which has or should have been] distinctly put in issue" ${ }^{\text {"6y }}$ by aggrieved party who has had his full and fair day in court. Besides helping to keep societal peace ${ }^{7}$ and protecting an individual litigant from harassment, ${ }^{8}$ finality lends stability and predictability to judicial activity-qualities essential to any institution charged with settling disputes authoritatively. ${ }^{9}$ On the other lrand, the rigidity of absolute finality could be intolerable. ${ }^{10}$ Sometimes, for example, the "right, question or fact" is not "distinctly put into issue" and there are compelling reasons why a court should relieve a party from the judgment.

The task of rule $60(\mathrm{~b})$ is, therefore, "to restrict the [courts'] power of self-correction along generally acceptable standards"11 without bearing down mercilessly on the parties' right to optimum justice for their individual claims. ${ }^{12}$ The friction between finality and individual justice can be alleviated if the problem is conceived not in terms of some definite time at which judgments suddenly acquire "finality," but in terms of "judgments gradually becom[ing] more final as time passes." ${ }^{\prime 13}$ Viewing the choice as one solely between finality and individual justice ${ }^{14}$ ignores many considerations that ought to affect a

5. Bankers Mortgage Co. v. United States, 423 F.2d 73, 77 (5th Cir.), cert. denied, 399 U.S. 927 (1970). See generally Moore \& Rogers, Federal Relief From Civil Judgments, 55 YALE L.J. 623, 623-26 (1946) [hereinafter cited as Moore \& Rogers].

6. Southern Pac. R.R. v. United States, 168 U.S. 1, 48 (1897) (emphasis added).

7. Id. at 48-49.

8. E.g., Restatement of Judgments $\$ 126$, comment $c$, at 613-14 (1942); Recent Decisions, 40 Mich. L. Rev. 598, 599 (1942).

9. E.g., Moore \& Rogers 626.

10. Id.

11. Id.

12. See, e.g., 1954 .DRAFT 56, commenting in relation to a proposed extension of the one-year limitation of rule $60(\mathrm{~b})(1)-(3)$ that "[t]he amendment destroys no real elements of finality in federal jndgments, for experience has shown that the courts maintaim a scrupulous regard for the proper aims of finality," citing Note, Federal Rule 60(b): Relief From Civil Judgments, 61 YAIE L.J. 76, 86 (1952).

13. Comment, Temporal Aspects of the Finality of Judgments-The Significance of Federal Rule 60(b), 17 U. CHI. L. REv. 664, 674 (1950). Cf. Moore \& Rogers 693 (calling for a "flexible concept" of finality by allowing the court to apply its principles with "an understanding flexibility").

14. See, e.g., Note, Fraud as a Basis for Setting Aside a Judgment, 21 CoLUM. L. Rev. 268, 269 (1921), wherein the writer, after balancing in a general sense the arguments for and against relief from intrinsic fraud, says that finality must always prevail in sucl cases. 
court's decision on the issue of relief. ${ }^{15}$

\section{A. Relief from Final Judgments Prior to the Federal Rules}

Only vague procedures governed relief from a final determination before the adoption of the Federal Rules. ${ }^{16}$ In general a federal district court had plenary power over a judgment in law or equity only during the term in which the case was decided; unless one party began procedures for relief in that term, or unless the court reserved power over the judgment, no relief could be given. ${ }^{17}$ This rigid rule was often inequitable, ${ }^{18}$ and several mitigating procedures developed: (1) ancillary remedies such as writs and bills; (2) independent actions for relief based on extrinsic fraud, mistake, or accident; and (3) exercise of the inherent power of a court over its prior judgments to disregard void judgments.

Ancillary remedies were available only from the rendering court. ${ }^{10}$ At law the two remedies were audita querela and writ of error coram nobis (or coram vobis). ${ }^{20}$ The former was an independent common law action by which relief could be obtained upon grounds arising before or after the judgment. Extrinsic fraud and lack of personal jurisdiction over the defendant exemplify grounds that arose prior to judgment; ${ }^{21}$ subsequent discharge of the judgment and reversal of an earlier judgment upon which the judgment rehed were typical postjudgment grounds. ${ }^{22}$ Coram nobis was a writ to the rendering court to have a judgment set aside for clerical error in fact; the writ did not lie for errors of judgment. ${ }^{23}$ The grounds for the use of either were never very clear, leading to conflicting and overly technical results. ${ }^{24}$ Common

15. See text accompanying notes 208-23 infra.

16. 1945 DRAFT 73 (They are "shrouded in ancient lore and mystery"); Comment, supra note 13, at 664 (They "were not clearly defined, were cumbersome, and made no pretense of covering all the deserving cases").

17. 7 MOORE fTा $60.09,60.16[2]$; Moore \& Rogers 626 and cases cited at 627 n.7.

18. The rule was arbitrary in allowing judgments rendered early in a term more time to be set aside or amended than those rendered later in a tern. Moore \& Rogers 629; Comment, supra note 13 , at 666 .

19. Moore \& Rogers $659,669,676$.

20. The distinction between the teruns is nominal. Coram vobis was a writ in "Common-Pleas, the record and process being stated to remain before the king's justices," while coram nobis was a writ "in the King's Bench . . . so called from its being founded on the record and process, which are stated in the writ to remain in the court of the lord the king, before the king himself. ..." 7 MOORE $\{60.14$, at 46 , quoting 2 W. TIDd, Practice in Personal Actions 1056 (1807).

21. 7 MOORE $\llbracket$ 60.13, at $42-43$ and cases cited nn.33-35.

22. For a more detailed analysis see 7 MOORE $\pi 60.13$, at 41-43; Moore \& Rogers 664-68; Comment, supra note 13, at $664-65$ \& n.2. Rule $60(\mathrm{~b})(5)$ presently covers these grounds.

23. 7 MOORE If 60.14 .

24. 7 MOORE $\{60.14$, at 49,51 . Compare New England Furniture \& Carpet 
law laches set the time limitation for both remedies. ${ }^{25}$ As to matters preceding the judgment, audita querela and coram nobis were indistinguishable, ${ }^{26}$ and both were early supplanted by inotion. ${ }^{27}$

Equity's bill of review ${ }^{28}$ likewise had to be filed in the court rendering the decree. ${ }^{29}$ It gave retief for error of fact apparent on the record, ${ }^{30}$ for newly discovered evidence, ${ }^{31}$ for change in circumstances, ${ }^{32}$ and for mistake, inadvertence, or fraud. ${ }^{33}$ Laches set the time limit for each ground, except that a party had to claim rehef for error of fact apparent on the record within the time for appeal. ${ }^{34}$

The independent action for relief was a collateral attack on a judginent instituted in the same or a different court, generally on the ground that one party had not had an opportunity to present his claims fully before judgment. ${ }^{35}$ Courts used their inherent power over their own judgments to justify rehef for fraud upon the court, final injunctions that were no longer equitable, and void judgments. The power was generally invoked in those cases where the claim for rehef seemed coinpelling, but where there was no clearly articulated ground for rehef. ${ }^{36}$ A void judgment, ${ }^{37}$ though, could be attacked at any time ${ }^{38}$ by a variety of direct and collateral methods. ${ }^{39}$

\section{B. Relief from Final Judgments Under Rule 60(b): 1938-1946}

The new rule $60(\mathrm{~b})$ largely retained these inethods for relief. ${ }^{40}$

Co. v. United States, 2 F. Supp. 648 (D. Minn. 1931) with New England Furniture \& Carpet Co. v. Willcuts, 55 F.2d 983 (D. Minn. 1931).

25. 7 MOORE If 60.14, at 52; Moore \& Rogers 669. Judicial decisions or statutes in some states provided for specific time limits. 7 MOORE || 60.14 .

26. 7 MOORE \ा 60.14.

27. E.g., Picket v. Legerwood, 32 U.S. (7 Pet.) 90, $92-93$ (1833); Comment, supra note 13 , at $665-66$ n.7.

28. The difference between the bill of review and a bill in the nature of a bill of review is a technical one, irrelevant to American practice. Whiting v. Bank of the United States, 38 U.S. (13 Pet.) 5, 13 (1839).

29. 7 MOORE [ $60.15[1]$, at 53.

30. Id. \ $60.15[2]$.

31. Id. \ $60.15[3]$.

32. Id. \ $60.15[4]$.

33. Id. โ $60.15[5]$.

34. Id. $\pi 60.15[2]$, at 60 and cases cited at $60 \mathrm{n.14}$.

35. See text accompanying notes 103-23 infra.

36. 7 MOORe If 60.16[5], at 89-90; Moore \& Rogers 666.

37. For a discussion of the complex and confusing "principles as to valid and void judgments," see 7 MOORE $\{60.25[2]$.

38. Id. I $60.25[4]$.

39. Id. I $60.25[1]$.

40. Pursuant to the Federal Rules Enabling Act of 1934, 48 Stat. 1064 (now 28 U.S.C.A. $\S 2072$ ), the Supreme Court of the United States appointed an Advisory Committee, adopted its draft, and made the rules effective in 1938. FED. R. Crv. P. 86(a). 
The 1936 draft of the Federal Rules Advisory Committee provided for relief by motion, if made "with reasonable diligence and before the time for appeal has expired," for substantially the same grounds as under present rule $60(\mathrm{~b})$, except that it made no provision for relief from void judgments, judgments that had been satisfied, released, discliarged, or that had otherwise become inequitable; the clause providing for relief for "any other reason" ${ }^{* 1}$ was also missing. The draft expressly preserved the independent action ${ }^{42}$ but said nothing of ancillary remedies. The committee's final report in 1937, however, retreated substantially from the broad provisions of the 1936 draft. ${ }^{43}$ It provided for rehef by motion only for "mistake, inadvertence, surprise, or excusable neglect"; also, inotions had to be brought within a reasonable time not to exceed six inonths. Like the draft, the final report expressly preserved the action to permit relief on other grounds, but agaim it said nothing about ancillary remedies. ${ }^{44}$

Some commentators have asserted that the final report rule was inadequate, ${ }^{45}$ yet "[a]s construed, it operated reasonably well." confronted with problems of interpretation, federal courts often applied the interpretations of California courts. ${ }^{47}$ Moreover, the courts inter-

41. Preliminary Draft of Rules for Civil Procedure (3d draft) 115 (1936). There was no explicit mention of extrinsic and intrinsic fraud in subdivision (3). The Committee Note stated that rule 60 (b) "is an additional remedy aud is not intended to exclude the independent suit, or what was formerly known as a bill of review, or a petition to vacate a judgment." Id. at 115-16. The unincluded grounds are presently subdivisions (4)-(6). See note 1 supra.

42. Id. at 115-16.

43. Final Report of the Advisory Committee on Rules for Civil Procedure $39-40$ (1937).

44. Id.

45. See generally 7 Moore If 60.17, at 91; Moore \& Rogers 685-93; Note, History and Interpretation of Federal Rule $60(b)$ of the Federal Rules of Civil Procedure, 25 TEMP. L.Q. 77, 81, 82 (1951); Comment, supra note 13, at 669. A literal application of the rule would have allowed relief by motion only for the movant's own mistake, inadvertence, surprise, or neglect, and by independent aetion only for extrinsic fraud, mistake, and accident. There was no mention of fraud or newly discovered evidence as grounds for relief by inotion, nor ancillary remedies. The rule applied only to a judgment "taken against" the movant, although it was not restricted to final judgments, orders, or proceedings. Finally, the six-month limitation was too short, although rule $6(\mathrm{~b})$ technically allowed an extension.

46. 7 MOORE If 60.17, at 91. See also Coinment, supra note 13, at 669.

47. Fiske v. Buder, 125 F.2d 841, 844 (8th Cir. 1942). For a complete discussion of California's practice at that time and how it was used to liberalize federal practice under rule 60(b), see 7 Moore If 60.10; Moore \& Rogers 631-34. The Califormia statute was the model for rule 60(b). Notes to THE Rules of CTvil Procedure for the District Courts of the United States 57 (1938); Final Report of the Advisory Committee on Rules for Civil Procedure 40 (1937). Being without an adequate model for rule 60(b), the Advisory Committee followed a California member's recominendation and used California Civil Code $\$ 473$ as a model. See generally 7 MOORE If 60.10[1], at 10-11. 
preted rule 60 (b)'s clause permitting "an action" as preserving the independent action, ${ }^{48}$ coram nobis, ${ }^{49}$ audita querela, ${ }^{50}$ and the bill of review. ${ }^{51}$ This permitted the substance of the ancillary remedies to be used as grounds for relief by motion, which, if not excluded by the six-month limitation for the grounds stated, were subject only to laches. ${ }^{52}$

Questions arose whether the united procedure required by rule $2^{53}$ should be interpreted as providing only those remedies historically available either at law or in equity, because this could result in equally meritorious cases turning out differently. ${ }^{54}$ As one writer noted, "leaving the shrouded ancient writs to take care of the rest [of the grounds] would result in either a great injustice or a statute rendered meaningless by a host of court-made exceptions. Neither result is compatible with a modern code of procedure."

\section{Rule 60(b): The 1946 Amendments}

The Advisory Committee amended rule 60(b) to make all rehef available either by enunierated inotions or by independent action. ${ }^{56}$

48. Moore \& Rogers 634.

49. Preveden v. Hahn, 36 F. Supp. 952 (S.D.N.Y. 1941).

50. Jones v. Watts, 142 F.2d 575 (5th Cir. 1944).

51. Hazel-Atlas Glass Co. v. Hartford-Empire Co., 322 U.S. 238, 245 (1944); Fraser v. Doing, 130 F.2d 617 (D.C. Cir. 1942).

52. Moore \& Rogers 687. Courts seemed to agree that "an action" should be interpreted to preserve

the substance of the ancillary common law and equitable remedies, except insofar as their substance is specifically covered by some rule, and that in addition it preserves the independent action in equity; that the substance of the ancillary remedies may be obtained by motion in the original action. ... As a consequence the scope of the saving clause is shrouded in ancient lore and inystery.

Id. at 686.

53. Fed. R. Civ. P. 2: "There shall be one form of action to be known as "civil action."

54. This objection is stated in Moore \& Rogers 687:

And if, nevertheless, these remedies are expanded by judicial construction so that the common law remedies nay be utilized in present civil actions formerly equitable and the equitable remedies may be utilized in the present civil actions formerly legal, in addition to the type of action out of which they grew, there will still be situations, because of the historical growth of the old remedies, where relief will not be afforded, although these are as meritorious as situations where relief is granted.

See cases cited note 24 supra.

55. Note, supra note 45 , at 82 . The writer discusses Nachod \& United States Signal Co. v. Automatic Signal Corp., 32 F. Supp. 588 (D. Conn. 1940), a case where he felt relief seemed warranted but which fell under neither $60(\mathrm{~b})$ motions nor ancillary remedies. The court denied relief from its mistake of law because it interpreted rule 60 (b) (1) as applicable only to the movant's mistake. The writer adds that rehef by bill of review would have been demied because the mistake was not apparent on the face of the record.

56. 1945 DrAFT 72-73. The Committee hoped that by having all rehief avail- 
The amended rule represented an expansive, liberal approach to procedure: subdivision (1) no longer applied only to the movant's own mistake, inadvertence, surprise, or neglect, nor solely to judgments taken "against him"; the new rule included newly discovered evidence as grounds for relief in subdivision (2); it expressly included fraud as grounds for a motion and abolished the extrinsic-intrinsic distinction in subdivision (3); it added the "any other reason" clause as subdivision (6); it raised the time limitation under subdivisions (1)(3) from six months to one year; it made "fraud upon the court" a ground for relief; it substituted "an independent action" for "an action"; and it abolished the ancillary reinedies and provided that all relief thereafter was to be by motion or by independent action. ${ }^{67}$ In addition, rule $6(\mathrm{~b})$ was amended to exclude rule $60(\mathrm{~b})$ from its provisions for time extensions. ${ }^{58}$ Besides clarifying and expanding the procedure for relief froin final judgments, the new rule attempted "to buttress the finality of judgments against belated attacks or attacks upon unstated and ill-defined grounds." ${ }^{59}$ But it also postponed finality by extending the time limits to one year for the grounds stated in subdivisions (1)-(3) and by eliminating time limits entirely for the "any other reason" clause. ${ }^{00}$

Since the 1946 amendments to rule 60(b), federal courts have

able by specified motions or independent action the federal rules would "then deal with the practice in every sort of case in which relief froin final judgment is asked, and prescribe the practice."

57. See note 1 supra. On how ancillary rennedies were integrated into rule 60 (b), see 7 MOORE II 60.34.

58. FED. R. Crv. P. 6 provides that the court at its discretion, sua sponte or on motion, "for cause shown may" enlarge time limitations in the rules "but it may not extend the time for taking any action under Rule . . 60(b) . . except to the extent and under the conditions stated in [it]."

59. 7 MOORE $\Uparrow 60.18[1]$, at 202 . One commentator argues that subdivision (6), which dispenses with definite tine limits, represents "a new philosophy of judgments" and that theories justifying definite time periods are fallacious. Comment, supra note 13, at 672-74. The writer states that judgments were treated as "property rights [that] had vested ... and to upset a final judgment was to deprive someone of property by that very act" and notes that the reasoning in pre-Federal Rules practice was that "after the end of the term [courts] lost jurisdiction over the case." His answer is that the term rule only defines jurisdiction, and if the court can vest property it can also divest it. Moore \& Rogers 629-30 concur on the former argument, stating that rule 82 prohibits extension of jurisdiction by federal rule and that, historically and practically, relief from judgments has not been considered a question involving jurisdiction. But see United States v. Mayer, 235 U.S. 55 (1914), which defended the term rule on jurisdictional grounds.

60. See Note, Attacking Fraudulently Obtained Judgments in the Federal Courts, 48 IowA L. REv. 398, 401 (1963): "[B]ut [rule 60(b)] also tend8 to expand the court's power to accomplish justice ...." See also Klapprott v. United States, 335 U.S. 601, 614-15, modified, 336 U.S. 942 (1949); Comment, supra note 13, at 670-71; Note, Federal Rule 60(b): Relief from Civil Judgments, 61 YALE L.J. 76, 85-86 (1952). 
developed several general rules to guide them in its administration: the rule is liberally construed ${ }^{61}$ in accordance with equitable principles; ${ }^{62}$ the court's relief power is discretionary; ${ }^{63}$ and nomenclature should not be determinative of relief. ${ }^{.4}$ As so interpreted, rule $60(\mathrm{~b})$ may have struck a fair balance between finality and imdividual justice and on the whole lias led to strikingly sound decisions. ${ }^{65}$ Even those critical of certain aspects of the rule admit that it has incorporated the courts' experience "in a clear and workmanlike inanner." "Bs Nevertheless, as discussed in the introduction to this Comment, disagreement persists among courts and commentators about the relationship of the "any other reason" clause to grounds stated in subdivision (1)(3), about the circumstances under which "fraud upon the court" applies and its relationship to extrinsic and imtrinsic fraud, and about the wisdom of perpetuating the extrinsic-intrinsic fraud dichotomy in the independent action. Generally speaking, a more rational, flexible, and equitable treatment of the value of finality is needed, whereby courts refocus attention from the labels applied to grounds for relief in rule $60(\mathrm{~b})$ to the factors inherent in particular fact situations that call for rehief.

61. Klapprott v. United States, 335 U.S. 601, 614-15, modified, 336 U.S. 942 (1949); Michigan Sur. Co. v. Service Mach. Corp., 277 F.2d 531, 533 (5th Cir. 1960); 7 MOORE If 60.18[8], at 214. Cf. Cox v. Transworld Airlines, 20 F.R.D. 298, 300 (W.D. Mo. 1957).

62. Sutherland v. Fitzgerald, 291 F.2d 846, 847 (10th Cir. 1961); Tozer v. Charles A. Krause Milling Co., 189 F.2d 242, 246 (3d Cir. 1951); Assmann v. Fleming, 159 F.2d 332, 336 (8th Cir. 1947); Pierre v. Bernuth, Lembcke Co., 20 F.R.D. 116, 117 (S.D.N.Y. 1956); see United States v. Gould, 301 F.2d 353, 355, 357 (5th Cir. 1962).

63. Ackermann v. Umited States, 340 U.S. 193, 202 (1950); Klapprott v. United States, 335 U.S. 601, 614-15, modified, 336 U.S. 942 (1949); Byron v. Bleakley Transp. Co., 43 F.R.D. 413,415 (S.D.N.Y. 1967); 7 MOORE शी 60.19, at 223. The court in United States v. Karahahas, 205 F.2d 331, 333 (2d Cir. 1953), stated that subdivision (6) gives "the court a discretionary dispensing power over the limitations imposed by the rule itself on subsections (1), (2) and (3)" but retreated from this position on rehearing.

64. Klapprott v. United States, 335 U.S. 601, 614-15, modified, 336 U.S. 942 (1949); United States v. Jacobs, 298 F.2d 469, 472 (4th Cir. 1961) (relief by the court when its attention is directed to necessity thereof other than by motion); Bridoux v. Eastern Airlines, Inc., 214 F.2d 207, 209 n.3 (D.C. Cir.), cert. denied, 348 U.S. 821 (1954); Hadden v. Rumsey Prods., 196 F.2d 92 (2d Cir. 1952) (motion treated as independent action to obtain equitable relief); Tozer v. Charles A. Krause Milling Co., 189 F.2d 242 (3d Cir. 1951); In re Cremidas' Estate, 14 F.R.D. 15, 17 (D. Alas. 1953) (coram nobis treated as "any other reason" under subdivision (6)). But compare Ma Chuck Moon v. Dulles, 237 F.2d 241 (9th Cir. 1956), cert. denied, 352 U.S. 1002 (1957) (independent action will not be treated as a motion) with Bankers Mortgage Co. v. Umited States, 423 F.2d 73, 77 n.7 (5th Cir.), cert. denied, 399 U.S. 927 (1970).

65. 7 MOORE If 60.42 , at 902 .

66. Coninent, supra note 13, at 670 . 
II

\section{The Problem of Getting Relief from Fraud}

\section{A. What Grounds in Rule 60(b) Apply?}

Subdivision (3) of rule 60 (b) permits relief from either extrinsic or intrinsic fraud by motion within a reasonable time not to exceed one year, ${ }^{67}$ regardless of the procedure or terminology used by the applicant. $^{68}$ If, lowever, an independent action is brouglit in a court other than that which rendered the judgment or in the rendering court after one year, the court must determine whether the fraud is extrinsic or intrinsic ${ }^{69}$ and deny relief for intrinsic fraud. But the court must distinguish relief for "fraud upon the court," for which there is no time limit, froin relief by motion, for which there is a one-year limitation, and from relief by independent action, which is limited by laches. ${ }^{70}$ Moreover, if a court finds that the "any other reason" clause is available for rehef froin fraud, the extrinsic-intrinsic distinction may be irrelevant, even though courts make the distinction in the independent action, ${ }^{71}$ and the time limit is laches.

A recent case, Bros., Inc. v. W. E. Grace Manufacturing Co., ${ }^{72}$ exemplifies the need for amendment of rule 60(b)'s fraud provisions. In 1957, the plaintiff-patentee secured a judgment agamst the defendant for infringement in an Ohio federal court. Before the appellate court affirmed plaintiff's judgment, third parties obtained a Minnesota federal court declaratory judgment that the patent was invalid on the ground that a brochure describing the invention had been published more than one year before the patent application. The infringement

67. For text of the rule, see note 1 supra. See 7 Moore |f 60.24[1]-[3], at 245-50. for general discussion of relief prior to the fcderal rule.

68. 7 MOORE $\int 60.24$ [5], at $253-54$ and cases cited at $254 \mathrm{n.9}$; id. at 28 (Supp. 1970 ); id. \ा 60.24[4], at 252-53.

69. E.g., Dowdy v. Hawfield, 189 F.2d 637 (D.C. Cir.), cert. denied, 342 U.S. 830 (1951). See text accompanying note 104 infra for discussion of extrinsic and intrinsic fraud.

70. Hazel-Atlas Glass Co. v. Hartford-Empire Co., 322 U.S. 238, $245-46$ (1944).

71. Bros., Inc. v. W.E. Grace Mfg. Co., 320 F.2d 594, 608 (5th Cir. 1963). See also Note, Federal Rules 52(a) and 60(b)-A Chinese Puzzle, 21 Sw. L.J. 339, 446-47 (1967). Compare United States v. Karahalias, 205 F.2d 331, 333 (2d Cir. 1953) and Stevens v. Stoumen, 32 F.R.D. 385, 386-87 (E.D. Pa. 1963) (which argue subdivision (b) is applicable to any extraordinary circumstances) with Bros., Inc. v. W.E. Grace Mfg. Co., supra at 608 ("subsection (6) must mean to make available those grounds which equity has long recognized as a basis for rehief ....") (dictum). An allegation that the movant's wife conspired with his attorney to defraud him by obtaining a dismissal based on a settlement made without his knowledge or consent, has recently been held to state grounds for relief under (6) rather than (3) or an independent action. McKinney v. Boyle, 404 F.2d 632, 634 (9th Cir. 1968), cert. denied, 394 U.S. 992 (1969).

72. 320 F.2d 594 (5th Cir. 1963). 
defendant then claimed that the Ohio judgment and a Texas federal court summary judgment based thereon should be set aside for fraud, arguing that the patentee had knowingly submitted a false affidavit about the date of the brochure in the Ohio action. His motion for a new trial in the Texas action was treated as a $60(\mathrm{~b})$ inotion and was successful, although made more than one year after the Ohio judgment had become final.

Initially the case appeared to involve intrimsic fraud ${ }^{73}$ or newly discovered evidence. ${ }^{74}$ The Fifth Circuit, however, declared that relief "should be determined by substance, not a label," and treated the claim for relief as a rule $60(\mathrm{~b})$ motion, "which, if finally sustained after proof and hearing, would justify some character of equitable relief."'T5 Had it treated the motion as a subdivision (2) or (3) motion, relief would have been barred by the lapse of time; had it characterized the inotion as an independent action, relief would have been available only if the fraud were extrinsic. The independent action apphies only to extrinsic fraud, ${ }^{76}$ and though the court suggested that sucli fraud may liave been involved, ${ }^{77}$ its discussion of the relationship between the "any other reason" clause and grounds for relief in the first three subdivisions impliedly admitted that the facts could not fit the "extrinsic" label. ${ }^{78}$ Because the court deemed the issue of laches relevant, ${ }^{79}$ it is clear there was no fimding of "fraud upon the court," to which that issue is irrelevant. ${ }^{80}$ Its process of elimination thus leaves only the "any other reason" clause as the court's rationale.

The court's reasoning seems to have been that the labels under which a party is permitted relief from fraud are too difficult to apply consistently; that subdivision (3) declares the rule's policy against extrinsic-intrinsic distinction; that the "any other reason" clause was intended to make relief available on grounds long recognized in equity; and that if relief is equitable, the court will not give the fraud a label..$^{81}$ It follows from such reasoning that a defendant sliould also get relief by an independent action without regard to whether the fraud is called "extrinsic" or "intrinsic," since courts are to disregard mere

73. See text accompanying note 106 infra.

74. 320 F.2d at 603,608 .

75. Id. at 606-07.

76. See text accompanying notes 116-17 infra.

77. 320 F.2d at 609 .

78. Id. at 608. For a discnssion of this relationship, see text accompanying notes $208-23$ infra.

79. Id. at 610 .

80. Hazel-Atlas Glass Co. v. Hartford-Empire Co., 322 U.S. 238, 246 (1944).

81. 320 F.2d at 608 . 
nomenclature. ${ }^{82}$ Since relief from extrinsic fraud is limited only by laches in the independent action, the same treatment should follow under a motion, in this case an "any other reason" motion, since it alone is without the one-year limitation. The court's position is ultimately based, then, on the position that rule 60(b)'s categories are not amenable to practical apphication and that in order to reach equitable and just determination, courts must escape from the one-year limitation. ${ }^{83}$

\section{B. Relief by Independent Action}

The established rule is that an independent action may be used only for rehef from extrinsic fraud, mistake, or accident. The perpetuation of this extrinsic-intrinsic distinction has led the federal courts into a thicket of inconsistency, because the distinction is unnecessary, often irrational, and potentially productive of injustices not outweighed by the interests of finality.

\section{The Nature and Use of the Independent Action}

Rule 60(b) "does not limit the power of a court to entertain an independent action to relieve a party from a judgment, order, or proceeding," which permits, according to the Advisory Committee, "the granting of various kinds of relief from judgments which were permitted in the federal courts prior to the adoption of these rules . . .."85 Therefore, courts must delve into history to discover the grounds for relief. ${ }^{86}$

Generally, courts deem an independent action proper where a judgment has been taken without a party's opportunity to present his claims fairly. Thus, it lies for extrinsic fraud, ${ }^{87}$ fraud upon the court $^{88}$ void judgments, ${ }^{89}$ accident, ${ }^{90}$ mistake, ${ }^{01}$ and sometimes for

82. See note 64 supra.

83. Later cases in the Fifth Circuit are in accord. Laguna Royalty Co. v. Marsh, 350 F.2d 817, 823 (5th Cir. 1965); In re Casco Cheın. Co., 335 F.2d 645, 651

(5th Cir. 1964).

84. See note 1 supra.

85. 1945 DRAFT 72.

86. "[N]o attempt has been made to state the substantive bases for such an action." 7 MOORE $\mathbb{6}$ 60.37[1], at 606-07.

87. United States v. Throckmorton, 98 U.S. 61 (1898) (distinguishing extrinsic from intrinsic fraud). See text accoinpanying note 104 infra.

88. Hadden v. Rumsey Prods., 96 F. Supp. 988, 992 (W.D.N.Y. 1951), rev'd on other grounds, 196 F.2d 92 (2d Cir. 1952).

89. United States v. Cain, 72 F. Supp. 897 (W.D. Mich. 1947).

90. National Sur. Co. v. State Bank, 120 F. 593, 597 (8th Cir. 1903).

91. Hale v. Ralston Purina Co., 432 F.2d 156, 160 (8th Cir. 1970); West Virginia Oil \& Gas Co. v. George E. Breece Lumber Co., 213 F.2d 702, 706 (5th Cir. 1954). 
newly discovered evidence. ${ }^{92}$ This general rule is subject to the doctrine of res judicata, which precludes relitigation in an independent action of issues actually litigated or open to litigation in the prior action. ${ }^{03}$

A federal court may restrain the enforcement of a judgment or decree rendered in any court, ${ }^{94}$ including a state court, ${ }^{95}$ by means of the independent action. If brought in the rendering court within one year, it will be treated as a inotion, ${ }^{96}$ and the court has general revisory powers over the judgment whatever the application is called. ${ }^{97}$ If the action is brought in a different court and that court has no jurisdiction over the subject matter, the judgment remains unaffected; the court instead acts upon the unconscionable party..$^{98}$

Thus, application for relief by motion to the court that rendered the judgment is sufficient under subdivision (3); yet if the party apphes for relief from the rendering court after the one-year time limitation on motions has expired, he must employ-assuming that use of the "any other reason" clause is unavailable - an independent action. A motion would serve the saine purposes ${ }^{99}$ and should be allowed in

92. Pickford v. Talbott, 225 U.S. 651, 657, 658, 661 (1912); Harrington v. Denny, 3 F. Supp. 584, 591 (W.D. Mo.), appeal dismissed, 68 F.2d 1004 (8th Cir. 1933).

93. E.g., Dairy Distrib., Inc. v. Western Conference of Teamsters, 294 F.2d 348 (10th Cir. 1961), cert. denied, 368 U.S. 988 (1962).

94. 7 MOORE If 60.36, at 602-03; Moore \& Rogers 654 .

95. E.g., Griffith v. Bank of New York, 147 F.2d 899 (2d Cir. 1945); 7 Moore If 60.36, at 603 and cases cited n.13.

96. Sebastiano v. United States, 103 F. Supp. 278, 279 (N.D. Ohio 1951), aff'd, 195 F.2d 184 (6th Cir. 1952).

97. See West Virginia Oil \& Gas Co. v. George E. Breece Lumber Co., 213 F.2d 702, 705.06 (5th Cir. 1954).

98. Anon LITT 37, 124 Eng. Rep. 124 (1626) (while the chancellor cannot act on the judgment, "he nray proceed against the person for corrupt conscience, because he takes advantage of the law against conscience"); 7 MOORE $\Uparrow 60.36$, at 603 and cases cited therein. In this situation there may be problems relating to the federal courts' basis of jurisdiction. Moore \& Rogers 655 . There is generally no problem if the action is brought in the rendering court, because the courts find ancillary jurisdiction. E.g., Pacific R.R. v. Missouri Pac. Ry., 111 U.S. 505 (1884), and the recent cases cited in 7 MOORE $\int 60.38$ [1], at $60 \mathrm{n} .3$ (Supp. 1970). But if brought in a different court and conventional gronnds for jurisdiction are lacking, the court may not entertain the action. See 7 MOORE $\Uparrow$ 60.38[1], at 638-39. Whether state or federal law applies may also be a problem. See generally 7 MOORE $\$$ 60.37[2], at 626-30.

99. It may be argued that since so much time has passed, the imdependent action properly requires the party to plead his fraud or mistake with particularity. FED. R. Civ. P. 9(b): "In all avennents of fraud or mistake, the circumstances constituting fraud or mistake shall be stated with particnlarity." But particularity may also be required under a motion. FED. R. CTv. P. 7(b): "An application . . . by motion . . . shall be made in writing, shall state with particularity the grounds therefor, and shall set forth the relief . . . sought." Also, the court may require, under the "just terms" plırase of rule $60(\mathrm{~b})$, "a specific recitation of facts." Trueblood v. Grayson Shops, Inc., 32 F.R.D. 190, 196 (E.D. Va. 1963). 
such situations. Some courts have suggested that before the time for relief by motion lias expired, the party should always apply for relief in the rendering court ${ }^{100}$ to enable the court that originally lieard the controversy and thus is best informed about it to dispose of the motion. Even if this is not done, a 1404(a) transfer ${ }^{101}$ to the rendering court could achieve the same benefit. However, as one writer observes, "[i]n view of the third and sixth grounds [fraud and 'any other reason'], it is not apparent why the independent action in equity was still preserved." 102

\section{The Extrinsic-Intrinsic Distinction}

a. Experience in the federal courts-a puzzle. In 1853, one Richardson traveled from California to Mexico and returned with a falsely antedated grant to certain land in California. A federal board of commissioners confirmed the grant, that decision being affirmed by a federal district court decree in 1856. Richardson thereafter conveyed to good-faith purchasers. Twenty years after the decree, a United States attorney brought a bill in a California federal court to set aside the decree and have it declared null and void on the ground of the afterdiscovered fraud. In United States $v$. Throckmorton ${ }^{103}$ the United States Supreme Court affirmed the district court's denial of relief.

The Court buried its holding beneath a voluminous dictunt, whicl1 introduced the extrinsic-intrinsic distinction into fraud cases. Justice Miller reasoned that relief from fraud in a collateral attack on a decree is permitted only where

there was in fact no adversary trial or decision of the issue in the case [and] the unsuccessful party has been prevented from exhibiting fully his case, by fraud or deception practiced on him by his opponent, as by keeping him away from court, a false promise of a compromise; or where the defendant never had knowledge of the suit, being kept in ignorance by the acts of the plaintiff; or where an attorney fraudulently or without authority assumes to represent a party and connives at his defeat; or where the attorney regularly employed corruptly sells out his client's interest to the other side. . . .

On the other hand, the doctrine is equally well settled that the court will not set aside a judgment because it was founded on

100. E.g., Gundelfinger v. Mariposa Commercial \& Mining Co., 72 Cal. App. 2d 540, 165 P.2d 57 (3d Dist. 1946).

101. A federal court can, under 28 U.S.C. $\$ 1404(a)$, transfer the action to the rendering court: "For the convenience of parties and witnesses, in the interests of justice, a district court may transfer any civil action to any other district or division where it might have been brought." 7 MOORE $\{60.8[1]$, at 639-40 \& n.23.

102. Note, supra note 45 , at 83.

103. 98 U.S. 61 (1878). 
a fraudulent instrument, or perjured evidence, or for any matter which was actually presented and considered in the judgment assailed. ${ }^{104}$

However, the Court noted that no allegations were made about the conduct of the attorneys, agents, or other officers of the government. ${ }^{105}$ It suggested that the petitioner had several years to discover the fraud and that the grant's validity was the sole issue in both the confirmation and affirmation proceedings. ${ }^{\mathbf{1 0 0}}$ The Court mentioned only in its statement of facts that the defendants were innocent third parties. ${ }^{107}$ These factors alone would have been sufficient to deny relief, yet the Court proceeded to speak of "extrinsic" and "intrinsic" fraud and to give examples of situations-none of them before it-that fell under each heading, suggesting that relief is permitted only for the former.

In 1891 the Court set the stage for furtlier confusion in Marshall v. Holmes. ${ }^{108}$ One Mayer liad allegedly procured a series of state court judgments against Marshall on the basis of perjury and a forged letter. Over a year after the judgments, Marshall brought an action in the same court to enjoin the enforcement of the judgments on grounds of fraud and later petitioned to remove the case to a federal court. The Supreine Court held only that a federal court has jurisdiction of such an independent action where there is diversity of citizenship and a proper amount in controversy, and that therefore Marshall should have been allowed to remove the case to the federal court. ${ }^{109}$ The Court made no ruling on the substantive law of relief from fraud. This narrow holding was forgotten by later courts, which looked instead to the Court's dictum:

"[A]ny fact which clearly proves it to be against conscience to execute a judgment, and of which the mjured party could not have availed himself in a court of law, but was prevented by fraud or accident, unmixed with any fault or negligence in himself or his agents, will justify an apphication to a court of chancery." Marine Ins. Co. v. Hodgson, 7 Cranch 332, 336 . . . See also United States $v$. Throckmorton, 98 U.S. $61,65.110$

On the facts, there is assuredly no conflict between Throckmorton and Marshall, but citation of Throckmorton in light of the facts and its holding was unnecessary and confusing. Neither courts nor com-

104. Id. at 65-66.

105. Id. at 62,69 .

106. Id. at 64,69 .

107. See Bradburn v. McIntosh, 159 F.2d 925, 933 (10th Cir. 1947) ("Equitable relief, however, will not be granted as against an innocent third person who, in good faith, has acted on the faith of the challenged judgment").

108. 141 U.S. 589 (1891).

109. Id. at 600-01; see Annot., 126 A.L.R. 390, 406-07 n.42 (1940).

110. 141 U.S. at 596. 
mentators ${ }^{111}$ are in agreement on the meaning or relationship of the two dicta. Most federal courts generally claim to follow Throckmorton rather than Marshall, ${ }^{112}$ while some evade its substance with varying fidehty to its form. In Publicker v. Shallcross, ${ }^{113}$ for example, the

111. Some writers say there is only a conflict as the cases are interpreted by the lower federal courts. E.g., Note, Equitable Relicf Against an Award Obtained by Perjury; The Extrinsic-Intrinsic Fraud Distinction, 36 ILL. L. REv. 894, 895 (1942). Other writers say that there is a basic difference in court philosophy. 7 Moone I 60.37[1], at 612-17; Note, Attacking Fraudulently Obtained Judgments in the Federal Courts, 48 Iowa L. REv. 398, 406 (1963). Another group of critics argues that there is "a hazy region of uncertainty" as the two cases are applied and "an unreconcilable conflict" standing alone. E.g., Note, Fraud As A Basis For Setting Aside a Judgment, 21 Colum. L. Rev. 268, 268-69 (1921) (allows federal courts to go either way); Note, Attacking Fraudulently Obtained Judgments in the Federal Courts, 48 IowA L. REv. 398, 408-09 (1963) ("Therefore, either case stands as authority and is left for the choice of the various circuits"). A writer in the latter group concludes that "[u]nti] the Supreme Court re-defines its position the 'manifestly unconscionable' test will be the only test, and it will remain, as it has been, that despite Federal Rule 60(b) there is no federal rule at all." Comment, Invalidating a Judgment for Fraud . . . and the Significance of Federal Rule 60(b), 3 DUKE B.J. 41, 51 (1952).

112. E.g., Dowdy v. Hawfield, 189 F.2d 637 (D.C. Cir. 1951); Independence Lead Mmes Co. v. Kingsbury, 175 F.2d 983, 985, 987-88 (9th Cir. 1949); Bradburn v. McIntosh, 159 F.2d 925, 932-33 (10th Cir. 1947); Aetna Cas. \& Sur. Co. v. Abbott, 130 F.2d 40, 43-44 (4th Cir. 1942); Philhps Petroleum Co. v. Jenkins, 91 F.2d 183, 187 (8th Cir. 1937) (perjury held intrinsic); Fidehty Storage Co. v. Urice, 12 F.2d 143, 144-45 (D.C. Cir. 1926) (perjury held intrinsic, though appellants alleged diligence, witnesses not available in prior case, and there was clear, strong, and convincing evidence of perjury; the court cited Throckmorton as authority and cited Nelson v. Meehan, 155 F. 1 (9th Cir. 1907), for the proposition that Marshall did not modify Throckmorton); Pickens v. Merriam, 242 F. 363, 371-72 (9th Cir. 1917) (fraud by administrators of estate in procuring releases from heirs and in procuring approval of fraudulent final account held extrinsic 10 years later and relief allowed); National Sur. Co. v. State Bank, 120 F. 593, 597 (8th Cir. 1903) (summons not received through accident of corporation's agent under state law held extrinsic accident); United States v. Gleeson, 90 F. 778 (2d Cir. 1898) (perjury held intrinsic, and if there is a conflict between Throckmorton and Marshall, which the court doubted, Throckmorton rules); United States v. Rexach, 41 F.R.D. 180, 185 (D.C.P.R. 1966); International Indein. Co. v. Peterson, 6 F.2d 230, 232 (D. Minn. 1925) (perjury conspiracy, relief denied). See 7 MOORE II 630.37[1], at 616 n.38 for other cases following the Throckmorton rule.

Most states also follow the Throckmorton rule. A much cited case is Pico v. Cohn, 91 Cal. 129, 134, 25 P. 970, 971 (1891). For a good summary of California practice and cases, see D. Louisel \& G. Hazard, Pleading and Procedure Cases AND MATERIALs 1166-70 (1968), and for a general review of other state cases see Annot., 126 A.L.R. 390, 405 (1940) and cases cited therein. Two states, New Jersey and Wisconsin, do not recognize this rule. See Shammas v. Shammas, 9 N.J. 321, 328, 88 A.2d 204, 208 (1952); Recent Decisions, 36 MARQ. L. REv. 198, 200 (1952); Recent Decisions, 34 Maro. L. REv. 138, 140 (1950). England also rejects the rule. Cole v. Langford, 2 Q.B. 26 (1898); Vadala v. Lawes, 25 Q.B. 310 (C.A. 1890); Abouloff v. Oppenheimer \& Co., 10 Q.B. 295 (C.A. 1882); Flower v. Lloyd, 10 Ch. D. 327, 334 (C.A. 1879); see Kennedy v. Dandrick, 59 L.T.R. 351 (1943). Canada rejected the rule in Johnston v. Barkley, 10 Ont. L.R. 724, 728-29 (1905).

113. 106 F.2d 949, 950 (3d Cir. 1939). Publisher had fraudulently induced receivers, bond holders, and the special master to believe his total assets were less 
Third Circuit vacated a two-year-old bankruptcy order, stating that Throckmorton was no longer the law of the Supreme Court. The court said that Throckmorton was distinguishable, ${ }^{114}$ but that if a case on point arises, it would apply "the more salutary doctrine of Marshall v. Holmes" because it conflicts with Throckmorton and courts can go either way. ${ }^{115}$ Though some writers believe this case is distinguishable from intrinsic fraud cases because there was no adversary trial, ${ }^{110}$ others feel that Publicker coupled with Marshall vitiates Throckmorton. ${ }^{117}$ Nevertheless, no federal court has subsequently repudiated the Throckmorton rule on the authority of Publicker.

In Chicago, Rhode Island \& Pacific Railway v. Callicotte, ${ }^{118}$ an employer sought to set aside the personal injury judginent recovered by his employee and to enjoin its enforcement on the ground that the employee, with the aid of his family and friends, had so convincingly feigned paralysis of his lower limbs that the employer, and several doctors as well, were fooled. The Eighth Circuit found the fraud extrinsic and gave the employer the relief he requested. The opinion parenthetically found no conflict between Throckmorton and Marshall, ${ }^{119}$ and reasoned that the conspiracy's purpose was not merely to present a false case for the plaintiff, but also to prevent the defendant company from putting on its defense by having the "true history of the case . . . by . . . conspiracy, concealed" outside of court; thus the fraud was labelled extrinsic. ${ }^{120}$ The better test would be not whether

than they were. The court cited Note, Injunctions Against the Enforcement of Judgments Obtained by Perjury, 22 HaRv. L. Rev. 600 (1909), which argued from Boring v. Ott, 138 Wis. 260, 119 N.W. 865 (1909), that with appropriate safeguards the lesser evil is to allow relief from intrinsic fraud. See also Comment, Equitable Relief From Judgments, Orders and Decrees Obtained By Fraud, 23 CALIF. L. REv. 79, 85 (1934) (making the same argument in discussing California cases); Recent Cases, 49 HARv. L. REv. 327 (1935) (arguing that in arbitration proceedings there should be an exception to the Throckmorton rule).

114. 106 F.2d at 950-51. The court distinguished Throckmorton on two grounds. First, the bankruptcy master had no reason to treat Publicker "as a possibly 'unscrupulous antagonist'" and therefore failed to minimize the risk of perjury by conducting a full adversary proceeding. Second, the court had "an interest in ascertaining the truth on behalf of the creditors, bondholders, etc., committed to its guidance" and hence the "perjury . . . impinged directly upon the administration of justice."

115. Id. at 951-52.

116. E.g., Recent Decisions, 40 Mrch. L. REv. 598, 599 (1942). See note 114 supra.

117. Note, Attacking Fraudulently Obtained Judgments in the Federal Courts, 48 Iowa L. Rev. 398, 407 (1963), citing 7 MOORE \ा 60.37[1], at 614-15. Moore, however, emphasizes the lack of a private adversary as a distinction [id. at 613-14 n.31]. Cf. Shammas v. Shammas, 9 N.J. 321, 329, 88 A.2d 204, 208 (1952): "Whether the Throckmorton principle is still controlling law in the federal courts is not clear" (citing Marshall and Publicker).

118. 267 F. 799 (8th Cir.), cert. denied, 255 U.S. 570 (1920).

119. Id. at 806 .

120. Id. at 802,809 . While some writers argue Callicotte adheres to Throck- 
the perjury was conspiratorial but whether in light of all the circumstances the fraud made a full and fair trial on the merits highly unlikely.

The Callicotte reasoning has been urged in subsequent cases, but has never been adopted. ${ }^{121}$ Thus, the Throckmorton dictum is still the major federal rule, though various courts liave either based relief on the broad Marshall basis ${ }^{122}$ or have otherwise indicated an unwillingness to determime the question according to the Throckmorton rule. ${ }^{123}$

b. An analysis of the extrinsic-intrinsic distinction. While the results reached under Throckmorton are on the whole sound and warranted in the interest of finality, in borderline cases a more just result is attainable:

[Courts should weigh] the degree of fraud and the diligence with which such was unearthed and proceeded on; hold the claimant for relief to strict standards of pleading fraud and other elements necessary to sustain his action and to clear and convincing proof, if the case reaclies that stage; and resolve any doubts against relief and in favor of the finality of the judgment attacked. ${ }^{124}$

morton [e.g., Note, Fraud as a Basis for Setting Aside a Judgment, 21 CoLum. L. Rev. 268,270 (1921)], the judgment was no more fraudulently procured than any that results from successful perjury (7 MOoRE $\{60.37[1]$, at 614). It is difficult to distinguish this case from that where a nonnegligent defrauded party is unable to bring in his witness [Fidehty Storage Co. v. Urice, 12 F.2d 143 (D.C. Cir. 1926)], or has no witness other than his adversary's bribed witness [Pico v. Cohn, 91 Cal. 129, 25 P. 970 (1891)].

121. E.g., Phillips Petroleum Co. v. Jenkins, 91 F.2d 183, 187 (8th Cir. 1937) (Callicotte inapplicable since alleged fraud was express issue at trial, and conspiracy was not proveu); International Indem. Co. v. Peterson, 6 F.2d 230, 232 (D. Minn. 1925) (Callicotte distinguished on the dubious ground that although the plaintiff, his doctor, and witnesses may have lied about plaintiff's prior condition, the plaintiff was in fact mjured); see Aetna Cas. \& Sur. Co. v. Abbott, 130 F.2d 40, $43-44$ (5th Cir. 1942).

122. E.g., National Sur. Co. v. State Bank, 120 F. 593, 598 (8th Cir. 1903); cf. Hazel-Atlas Glass Co. v. Hartford-Empire Co., 322 U.S. 238, 244-45 (1944).

123. E.g., Fiske v. Buder, 125 F.2d 841, 849 (8th Cir. 1942). Compare Atchison, T. \& S.F. Ry. v. Barrett, 246 F.2d 846, 849 (9th Cir. 1957) with Toledo Scale Co. v. Computing Scale Co., 261 U.S. 399, 421 (1923).

124. 7 MOORE If 60.37[1], at 614-15. Cf. Hazel-Atlas Glass Co. v. HartfordEmpire Co., 322 U.S. 238, 248 (1944); 3 W. Barron \& A. Holtzoff, Federal PracTTCE AND PROCEDURE §§ 1326, 1331, at 431-32, § 1331, at 254 (Supp. 1967); 3 A. FreEMAN, JUDGMENTS \& 1233, at 2570-71, 2584 (5th ed. 1925); Note, Attacking Fraudulently Obtained Judgments in the Federal Courts, 48 Iows L. Rev. 398, 409 (1963); Note, Intrinsic and Extrinsic Fraud and Relief Against Judgments, 4 VAND. L. Rev. 338, 342-43 (1951); Note, 12 CoRnELl L.Q. 385, 390-91 n.33 (1927); Recent Decisions, 40 MrCH. L. Rev. 598, 599-600 (1942); Comment, supra note 111, at 50. One writer even suggests, contrary to the accepted interpretation, that this reformulation is possible simply by reading rule $60(\mathrm{~b})$ as it stands. "The plain language of the rule seems to give carte blanche authority to a court to grant relief at any time for any type of fraud." Id. at 41. 
Furthermore, if the theory behind rule $60(\mathrm{~b})$ is that justice requires relief in cases where there was in fact no adversary trial or decision of the issue, ${ }^{125}$ it is doubtful that the distinction as applied comports with the theory. A more consistent approacl would be the following rule: "If the fraud really prevents the complaining party from making a full and fair defense it will justify setting aside a decree, whether extrinsic or intrinsic."126 Surprisingly, the central question whether the party was really prevented from having a fair trial never seems to be discussed in the cases, and the arguments for retaining the distinction often seem to argue as well for denying all relief, regardless of the distinction.

One may concede the abstract difference between fraud that tricks a party into forgoing his defense or claim and fraud that renders a party's defense or claim worthless by use of perjury or false documents at a trial or hearing. Yet, the fundamental argument against the distinction is that courts cannot rationally apply its categories to particular facts. ${ }^{127}$ The experience of the California courts in attempting to apply the distinction is one of confusion and uncertainty. ${ }^{128}$ The federal courts have likewise found substantial difficulties in making the distinction work. ${ }^{129}$ But even if the court can formally make the distinction, it may not be a distinction relevant to rational administration of justice. It is instructive to consider the specific arguments given to exclude relief from perjury or false and fraudulent documents:

125. This theory has been variously stated, as prevention of "a fair submission of the controversy" as opposed to "submit[ting] a matter, or hav[ing] had the opportunity of submit[ting] it" [Pico v. Cohn, 91 Cal. 129, 133, 25 P. 970, 971 (1901)]; as "fraud, accident or mistake which prevented the defendant in the judginent from obtaining the benefit of his defense" and "the absence of fault or negligence on the part of the defendant" [National Sur. Co. v. State Bank, 120 F. 593, 599 (8th Cir. 1903)]; and as preventing "the losing party from fully and fairly presenting his case or defense" [Atchison, T. \& S.F. Ry. v. Barrett, 246 F.2d 846, 849 (9th Cir. 1957)].

126. Fiske v. Buder, 125 F.2d 841, 849 (8th Cir. 1942) (dictum).

127. See A. FREEMAN, supra note $124, \S 1233$, at 2507 ("M]t may be doubted whether in some cases it is possible to say whether the fraud is extrinsic or intrinsic."); Moore \& Rogers 658 ("Furthermore at times it is a journey into futility to atteinpt a distinction between extrinsic and imtrinsic matter."); D. LouIsell \& G. HAZARD, supra note 112, at 1181-84 (Califomia courts' "journey into futility"); Note, RemediesFraud on Court, 1942 WIS. L. REv. 131.

128. Compare, e.g., Caldwell v. Taylor, 218 Cal. 471, 23 P.2d 758 (1933) (extrinsic fraud where defendant misrepresented to her deceased husband and then to plaintiff, her son, that she was previously unmarried and respectable, so that the period to contest probate ran without plaintiff's contesting) with Stenderup v. Broadway State Bank, 219 Cal. 593, 28 P.2d 14 (1933) (extrinsic fraud where defendants, trustees for collection of notes, testified falsely in court as to amount of collections actually received). See Levinson v. Bank of America, 126 Cal. App. 2d 122, 271 P.2d 632 (1954) (intrinsic fraud); Coinment, Equitable Relief From Judgments, Orders and Decrees Obtained By Fraud, 23 CALIF. L. REv. 79 (1934).

129. See text accompanying notes 103-23 supra. 
[A party should be prepared] to meet and expose perjury then and there. He knows that a false claim or defense can be supported in no other way; that the very object of the trial is, if possible, to ascertain the truth from the conflict of evidence, and that, necessarily, the truth or falsity of the testimony must be determined in deciding the issue. The trial is his opportunity for making the truth appear. ${ }^{130}$

However, under some circumstances the burden of exposing fraud at trial may be intolerable; ${ }^{131}$ the inquiry ought to be whether under the circumstances the party exercised all possible diligence and care in meeting the fraud of his adversary. ${ }^{132}$

The Eiglith Circuit recognized the force of this argument in a case where a conspiracy among the defendant and others precluded the discovery of rebuttal evidence. ${ }^{133}$ But if the rationale in the conspiracy case is the difficulty of rebuttal, that difficulty should be the issue, not, for example, the fact of conspiracy. Thus, perjury when the adversary cannot possibly secure the testimony of an essential witness, ${ }^{134}$ or bribery of the only nonparty witness with knowledge of the transaction, ${ }^{135}$ are as difficult of rebuttal as a conspiracy case; yet rehef is denied, even when perjury is conceded. ${ }^{136}$

Another justification for the extrinsic-intrinsic distinction is that only the rendering court is in a position to try the issue of perjury. ${ }^{137}$

130. Pico v. Cohn, 91 Cal. 129, 134, 25 P. 970, 971 (1891). See Dowdy v. Hawfield, 189 F.2d 637, 638 (D.C. Cir. 1951); Fidelity Storage Co. v. Urice, 12 F.2d 143, 144 (D.C. Cir. 1926); Bolden v. Sloss-Sheffield Steel \& Iron Co., 215 Ala. 334, 335, 110 So. 574, 575 (1926); 3 A. FreEMAN, supra note 124, \$ 1241, at 2582 and cases cited n.10; Case Note, 12 CoRNell L.Q. 385, 388 (1927).

131. E.g., Pico v. Cohn, 91 Cal. 129, 25 P. 970 (1891) (defendant paid the only witness to the transaction for his perjury).

132. "It is, or should be, sufficient for counsel to prepare to meet legitimate evidence. It would be an intolerable burden upon counsel to compel them to prepare to meet all possible varieties of perjured testimony. There is no such duty. . . ." Recent Cases, 21 ILl. L. Rev. 833, 836 (1927). "But he has a right to act upon the presumption that the opposite party, when sworn, will not commit perjury. We, therefore, do not think that it was negligent for the defendant to go to trial relying on the plaintiff Haven testifying truly in regard to the agency of Scofield." Stowell v. Eldred, 26 Wis. 504, 509 (1870).

133. Chicago, R.I. \& Pac. Ry. v. Callicotte, 267 F. 799 (8th Cir. 1920).

134. See Fidehity Storage Co. v. Urice, 12 F.2d 143 (D.C. Cir. 1926).

135. Pico v. Cohn, 91 Cal. 129, 25 P. 970 (1891). Cf. Boring v. Ott, 138 Wis. 260, 269, 119 N.W. 865,868 (1909) (emphasis added):

[Where relief is given from a party's perjury with respect to a contract claim presented against an estatel the fact that there was no adversary trial upon the issue of rescission which would have been a defense if established in favor of Boring is an element which should appeal to the conscience of the chancellor in determining the right to equitable relief.

136. Pico v. Cohn, 91 Cal. 129, 25 P. 970 (1891).

137. Note, Fraud As A Basis For Setting Aside A Judgment, 21 Colum. L. Rev. 268, 269 (1921). 
The judge in another court lacks the advantage, for example, of on-thespot observation of the witness' demeanor. However, the distinction is not limited to relief sought in another court but applies to the rendering court as well. Furthermore, a section 1404(a) transfer could eliminate the problem. ${ }^{138}$ Difficulties arise, of course, if the party attacking the judgment cannot get jurisdiction over the party defending it in the rendering court, or if the action is in a federal court on the basis of a judgment rendered in a state court. Yet where perjury precluded a full and fair trial, the second court is in no worse position to determine whether to grant relief than it would be in a case of extrinsic fraud.

A more frequently mentioned justification for excluding relief in perjury cases is that litigation must end and that granting relief will encourage retrials ad infinitum. ${ }^{139}$ Thus, the question is often phrased in terms of whether the greater evil is retrial or the denial of justice to a particular individual. ${ }^{140}$ And besides administrative problems, there may be a need to protect innocent parties from vexation. ${ }^{141}$

Several persuasive decisions, however, have rejected this ad infinitum arguinent. ${ }^{142}$ As early as 1870 the Wisconsin supreme court held that where perjury was material to a judgment and was not the result of the defendant's fault or neghigence, an action to enforce the

138. Problems with transferring can, however, arise; compare notes 98,101 supra.

139. Pico v. Cohn, 91 Cal. 129, 133, 134, 25 P. 970, 971 (1891):

The wrong in such case, is of course a most grievous one . . . [but endless] litigation, in which nothing was ever finally determined, would be worse than occasional miscarriages of justice; and so the rule is, that a final judgment cannot be annulled merely because it can be shown to have been based on perjured testimony; for if this could be done once, it could be done again and again ad infinitum.

See United States v. Throckmorton, 98 U.S. 61, 68-69 (1878); Dowdy v. Hawfield, 189 F.2d 637, 638 (D.C. Cir. 1950); Fidelity Storage Co. v. Urice, 12 F.2d 143, 145 (D.C. Cir. 1926); International Indern. Co. v. Peterson, 6 F.2d 230, 232 (D. Minn. 1925); Ross v. Wood, 8 Hun. 185, 187 (N.Y. 1876); 3 A. Freeman, supra note 124, $\$ 1241$, at 2582; Case Note, 12 CorNell L.Q. 385, 387 (1927) and cases cited therein. But see Johnston v. Barkley, 10 Ont. L.R. 724, 728-29 (1905) (relief froin perjury may be proper despite the possibility of spurring new trials).

140. E.g., Pico v. Cohn, 91 Cal. 129, 134, 25 P. 970,971 (1891); Note, Remedies-Fraud on Court, supra note 127, at 134. One response is that, at least in a different court, the remedy is not a new trial but "the enjoining of the person of the guilty party." Note, Intrinsic and Extrinsic Fraud and Relief Against Judgments, 4 VAND. L. REv. 338, 339-40 (1951). Nevertheless, a trial is required on the issue of the fraud, and merely to restrain the party, while sufficient in the case of a wronged defendant, is only the first step in reasserting a claim by a wronged plaintiff.

141. RESTATEMENT OF JUDGMENTS, § 126, comment $c$, at 613-14 (1942).

142. See generally Note, supra note 127; Note, Equitable Relief Against An Award Obtained By Perjury: The Extrinsic-Intrinsic Fraud Distinction, 36 IrI. L. REv. 894, 896 (1942); Note, Attacking Fraudulently Obtained Judgments in the Federal Courts, 48 Iowa L. REv. 398, 408; Note, Intrinsic and Extrinsic Fraud and Relief Against Judgments, 4 VAND. L. Rev. 338, 341 (1951). 
judgment would be enjoined. ${ }^{143}$ The same court reaffirmed this position in 1909 when it explicitly refused to follow the Throckmorton rule in Boring v. Ott. ${ }^{144}$ Nevertheless, since that time only nine cases dealing with "intrinsic" fraud have come before Wisconsin's appellate courts. ${ }^{145}$ The rationale for this liberal position rests on the equity powers of a court to reheve parties from unconscionable judgments, ${ }^{140}$ and the courts require a strong showing by the party seeking relief; ${ }^{117}$ it therefore appears that the finality of Wisconsin judgments has not been unduly harmed. ${ }^{148}$

By following Wisconsin's approach and limiting the occasions for relief, other courts could achieve similar results. Courts could insist, for exainple, that the fraud pertain to a material fact; ${ }^{149}$ that the party seeking relief not be guilty of laches ${ }^{150}$ or negligence, nor be at fault in the first instance; ${ }^{151}$ that he have a good claim or defense; ${ }^{162}$ that the fraud complained of be proven clearly and convincingly; ${ }^{163}$

143. Stowell v. Eldred, 26 Wis. 504 (1870).

144. 138 Wis. 260, 269, 119 N.W. 865,867 (1909).

145. Weber v. Weber, 260 Wis. 420, 51 N.W.2d 18 (1952) (relief from perjury allowed in divorce settlement upon which judgment of divorce based); Amberg v. Deaton, 223 Wis. 653, 271 N.W. 396 (1937) (relief from perjury allowed); Federal Life Ins. Co. v. Thayer, 222 Wis. 658,269 N.W. 547 (1936) (the showing required of defrauded party to prove perjury was not met); Grady v. Meyer, 205 Wis. 147, 236 N.W. 569 (1931) (defrauded party was negligent); Schulteis v. Trade Press Pub. Co., 191 Wis. 164, 210 N.W. 419 (1926) (same; laches); First Nat'I Exch. Bank v. Harvey, 176 Wis. 64, 186 N.W. 215 (1922) (plaintiff suing on default judgment cannot be enjoined for perjury where the defendant is guilty of laches); Royal Indem. Co. v. Sangor, 166 Wis. 148, 164 N.W. 821 (1917) (action treated as one at law for damages as a result of the defendants' conspiracy to defraud); Komorowski v. Jackowski, 164 Wis. 254, 159 N.W. 912 (1916) (rehef for procuring probate of forged will); Laun v. Kipp, 155 Wis. 347, 145 N.W. 183 (1914) (Stowell and Boring approved but relief also allowable for fraud upon the courts by respondent's attorney). See also Recent Decisions, 36 MARQ. L. REv. 198, 200 (1952).

146. E.g., Laun v. Kipp, 155 Wis. 347, 371, 145 N.W. 183, 192 (1914).

147. E.g., Amberg v. Deaton, 223 Wis. 653, 659, 271 N.W. 396, 398 (1937).

148. See Recent Decisions, 36 MarQ. L. Rev. 198, 200 (1952).

149. Weber v. Weber, 260 Wis. 420, 451, 51 N.W.2d 18, 23 (1952); Stowell v. Eldred, 26 Wis. 504, 508 (1870); see Shammas v. Shammas, 9 N.J. 321, 330, 88 A.2d 204, 208 (1952).

150. Schulteis v. Trade Press Pub. Co., 191 Wis. 164, 165, 210 N.W. 419, 419 (1926); Laun v. Kipp, 155 Wis. 347, 371, 145 N.W. 183, 192 (1914); Stowell v. Eldred, 26 Wis. 504, 508 (1870).

151. Amberg v. Deaton, 223 Wis. 653, 659, 271 N.W. 396, 398 (1937); Grady v. Meyer, 205 Wis. 147, 152, 154, 236 N.W. 569, 572 (1931); First Nat'l Exch. Bank v. Harvey, 176 Wis. 64, 69, 186 N.W. 215, 217 (1922); Laun v. Kipp, 155 Wis. 347, 371, 145 N.W. 183, 192 (1914); Boring v. Ott, 138 Wis. 260, 271, 119 N.W. 865, 868 (1909); Stowell v. Eldred, 26 Wis. 504, 508 (1870).

152. Stowell v. Eldred, 26 Wis. 504, 510 (1870).

153. Amberg v. Deaton, 223 Wis. 653, 659, 271 N.W. 396, 398 (1937); First Nat'1 Exch. Bank v. Harvey, 176 Wis. 64, 68, 186 N.W. 215, 216 (1922); Royal Indem. Co. v. Sangor, 166 Wis. 148, 149, 164 N.W. 821, 822 (1917); Boring v. Ott, 
and that the fraud have been willful or intentional, ${ }^{154}$ except, perhaps, in cases where the wrongful party is in a fiduciary relationship with the wronged party. ${ }^{155}$ The fear that a controversy will never come to rest if relief from perjury is allowed may well be overstated. Perjury entails such substantial risks that most parties might well choose simply not to pursue the case further. ${ }^{156}$ An occasional relitigation is better than arbitrary denial of rehef under the intrinsic label ${ }^{157}$ where equitable considerations suggest relief as forcefully as in the case of extrimsic fraud. ${ }^{158}$

\section{Fraud upon the Court}

The 1946 amendment made "fraud upon the court" an express ground for retief under rule $60(\mathrm{~b})$, but the meaning of the phrase was left in doubt. ${ }^{159}$ The logical starting point in a discussion of fraud upon the court is Hazel-Atlas Glass Co. v. Hartford-Empire Co. ${ }^{160}$ Hartford successfully sued Hazel in 1932 for patent infringement. In 1941, Hazel commenced proceedings in the same court, asking that the judgment be set aside on the ground that Hartford's attorney had actually written an article im a trade journal that he had attributed to an expert, using his publication to procure both the original patent and the judgment against Hazel. The circuit court denied rehef on three grounds: that the fraud was not newly discovered; that the article was not the primary basis of the 1932 decision; and that the term rule was applicable. ${ }^{161}$ The Supreme Court reversed, holding that notwithstanding Hazel's laches and lack of diligence, and even assuming that the article itself was legitimate and of hittle effect, two considerations compelled relief: the public importance of a patent suit and the integrity of the judicial process. ${ }^{162}$

Fraud by officers of the court, or by the court itself, has long been

138 Wis. 260, 274, 119 N.W. 865, 870 (1909). See Recent Cases, 21 ILl. L. REv. 833, 835 (1927) (citing cases allowing relief from perjury on various degrees of proof).

154. Shammas v. Shammas, 9 N.J. 321, 330, 88 A.2d 204, 208 (1952); Amberg v. Deaton, 223 Wis. 653, 659, 271 N.W. 396, 398 (1937).

155. Laun v. Kipp, 155 Wis. $347,364,373,145$ N.W. $183,189,192-93$ (1914).

156. Shammas v. Shammas, 9 N.J. 321, 329, 88 A.2d 204, 208 (1952); see Annot., 126 A.L.R. 390, 393 (1940).

157. Note, supra note 127, at 135.

158. Royal Indem. Co. v. Sangor, 166 Wis. 148, 150, 164 N.W. 821,822 (1917).

159. The Advisory Committee, in 1945 Draft 74 and 1946 Draft 84, left the phrase in as much doubt, much as in its treatment of the independent action. It merely cited Hazel-Atlas Glass Co. v. Hartford-Empire Co., 322 U.S. 238 (1944), for the proper use of such relief.

160. 322 U.S. 238 (1944).

161. See text accompanying notes 18-19 supra.

162. Id. at 246-47. See Hatch v. Ooms, 69 F. Supp. 788 (D.D.C. 1947) (the same attorney disbarred from Patent Office practice). 
recognized as a ground for relief, ${ }^{163}$ but there may be other grounds for fraud upon the court as well. Hazel-Atlas appears to rest on the attorney's direct involvement in defrauding the court on a matter of great public importance; otherwise, there would be hittle to distinguish it from Throckmorton, ${ }^{164}$ which also involved a substantial public interest (government granting of land patents), and in which the fraud was unquestionably material to the outcome. Yet the scope of the phrase "fraud upon the court" has not been so restricted in practice, which raises the difficult issues of whether Hazel-Atlas obviates the Throckmorton dictum, whether fraud upon the court applies only to extrinsic fraud, and whether any fraud is a fraud upon the court by being injurious to the public and to the administration of justice.

The first two questions can be answered together. Courts have long used "fraud upon the court" synonomously with "extrinsic fraud"105 rather than as a term of art, which rule 60(b) presumably intended. But under the reasoning of Hazel-Atlas, the terms "extrinsic" and "intrinsic" fraud are inapplicable. ${ }^{160}$ That Court allowed relief from

163. Universal Oil Prods. Co. v. Root Ref. Co., 328 U.S. 575 (1946); Root Ref. Co. v. Universal Oil Prods. Co., 169 F.2d 514 (3d Cir. 1948) (attorney bribed judge; judgment vacated even though defrauded party not willing to move for vacation); Ensminger v. Powers, 108 U.S. 292 (1883) ("legal fraud" upon the court for judge to abdicate duty of entering decree); Chicago Title \& Trust Co. v. Fox Theaters Corp., 182 F. Supp. 18 (S.D.N.Y. 1960) (alleged corruption by judge); American Ins. Co. v. Lucas, 38 F. Supp. 896 (W.D. Mo. 1940) (fraud upon the court where insurance companies' agent bribed state insurance superintendent); Platt v. Threadgill, 80 F. 192 (W.D. Va. 1897) (relief from verdict due to possibly prejudicial association between four jurors and a party).

164. United States v. Throckmorton, 98 U.S. 61, 69 (1878). The Court states that had the government agent taken part in the vendor's scheme the result would have been different. See text accompanying note 106 supra.

165. E.g., Keys v. Dunbar, 405 F.2d 955, $957-58$ (9th Cir.), cert. denied, 396 U.S. 880 (1969) (no fraud upon the court because the failure of state in a habeas corpus proceeding to produce a promised affidavit "did not prevent Keys from fully and fairly presenting his case"); Publicker v. Shallcross, 106 F.2d 949, 950 (3d Cir. 1939) (perjury by party held extrinsic and that it "impinged directly upon the administration of justice"); Chicago, R.I. \& P. Ry. v. Callicotte, 267 F. 799, 802 (8th Cir. 1920) (though no officer of the court was involved, the court referred to fraud as extrinsic and "against the court"); United States v. Rexach, 41 F.R.D. 180 (D.C.P.R. 1966) (fraud held extrinsic although the complaint was framed in terms of "fraud and deception upon the court" for the defendant's failure to disclose certain contracts). See Note, supra note 129 (discussing extrinsic fraud in terms of fraud on the court).

166. Some commentators, however, state that Hazel-Atlas itself, and its incorporation into rule $60(\mathrm{~b})$, were meant to apply only to extrinsic fraud. E.g., Note, Federal Rule 6O(b), 61 Y ALE L.J. 76, 79 n.17 (1952) (stating that cases have not distinguished betwcen independent action and fraud-upon-the-court rebef and that "[i]nsofar as fraud in either case nust be 'extrinsic' to warrant rehicf . . . the distinction between [them] neans little . ..."). Other writers argue that the classification of the fraud is irrelevant. E.g., Note, Attacking Fraudulently Obtained Judgments in the Federal Courts, 48 Iowa L. Rev. 398, 445-46 (1963). And one writer argues that the phrase permits relief only from some intrinsic fraud. $I d$. 
a fraud it felt had compromised the judicial process; its lack of concern for the parties involved is evident in its statements that the materiality of the fraud and the claimant's diligence were irrelevant considerations. ${ }^{167}$ While some courts have acknowledged the conflict of Hazel-Atlas and Throckmorton on this point, none has expressly accepted the argument that Hazel-Atlas repudiated Throckmorton. Some decisions, however, seem to imply acceptance. ${ }^{168}$ An example is Dausuel $v$. Dausuel, ${ }^{169}$ where a husband sought to vacate a divorce decree on the ground that his wife had falsely testified. Without discussion of the husband's diligence, his proof, or the time lapse since the decree, the court cited Hazel-Atlas to hold:

If, as appellant alleges, appellee testified falsely concerning these matters during the divorce proceedings she committed fraud on the court. Appellant should have been permitted to introduce the excluded evidence since it would tend to show that appellee testified falsely..$^{170}$

A clearer case of intrinsic fraud under the Throckmorton rule cannot be imagined. However, the result in such cases, under the rubric of "fraud upon the court," substantially threatens finality in view of

167. 322 U.S. at 246-47.

168. Consider Restatement of JUdGMENTS § 126, comment $c$, at 356-57 (Supp. 1942) (emphasis added):

Recent decisions make it doubtful whether the rule stated in subsection (2) clause (6) [\$126, stating extrinsic-intrinsic rule] would apply to the case of a judgment obtained by perjured testimony or the production of false documents if the perjured testimony or false statement had been knowingly procured by the successful party or his attorney.

The Restatement cites Hazel-Atlas and Sutter v. Easterly, 354 Mo. 282, 189 S.W.2d 284 (1945) (holding that it is fraud upon the court if attorney suborns a material witness to perjure his testimony) as the reason for the change and says that these cases "are both directly in conflict with the phrase deleted from the original comment c ...." Since both cases dealt only with attorneys' fraudulent acts, and intrinsic fraud has always included fraud knowingly procured, recent decisions do not warrant such a new rule as applied to the "successful party."

169. 195 F.2d 774 (D.C. Cir. 1952).

170. Id. at 775. In Haggar Co. v. United States, 128 F. Supp. 404 (Ct. Cl. 1955), the plaintiff sued for the price of clothing sold to the defendant, claiming that if an earlier judgment was res judicata, it was invalid for fraud upon the court since the Army had submitted a knowingly false affidavit regarding its disposition of certain of the clothing. The court held: "If a plaintiff practices fraud in the prosecution or proof of his case in our court, he forfeits his claim, no matter low neritorious his clain may otherwise lave been, or how supererogatory may have been his attempted fraud. We cannot tolerate being misled into unjust judgments by answers to our calls which give us false impressions as to material facts . . ." Id. at 407. The Haggar court did not cite Hazel-Atlas, but the case seems analogous to Dausucl. But cf. Josserand v. Taylor, 159 F.2d 249, 253 (C.C.P.A. 1946), where the court dismissed a Dausuel-type claim, saying "No mention was made in the court's opinion of the terms 'extrinsic' or 'intrinsic' fraud. Furthennore, we think it is clear from the decision in that case that the court was of opinion that the fraud therem referred to was extrinsic or collateral to the issues. ..." 
Hazel-Atlas' refusal to consider questions of diligence and materiality. ${ }^{171}$ Therefore, both extrinsic and intrinsic fraud should be distinguished from fraud upon the court:

Fraud upon the court should . . . embrace only that species of fraud which does, or attempts to, defile the court itself, or is a fraud perpetrated by officers of the court so that the judicial machinery cannot perform in the usual manner its impartial task of adjudging cases that are presented for adjudication. Fraud inter partes, without more, should not be a fraud upon the court, but redress should be left to a motion under $60(\mathrm{~b})(3)$ or to the independent action. ${ }^{172}$

This test, however, leaves unanswered the question whether all fraud will "defile the court itself." In a general sense an affirmative answer may be required, ${ }^{173}$ but it is imperative that limits to HazelAtlas be set, or else judgments could be vulnerable to attack at any time. The most likely limitation will come from the public importance of the issue in Hazel-Atlas. ${ }^{174}$ This can be seen in the denaturali-

171. 7 MOORE $\{60.15[5]$, at $68, \Uparrow 60.28$ [2], at 323 . Consider also id. $\{60.33$, at 509: "[I]f 'fraud upon the court' is not kept within proper limits but is ballooned to include all or substantially all species of fraud within $60(\mathrm{~b})(3)$ then the time limitation upon 60(b)(3) motions will be meaningless." Moore cites Note, Federal Rule 60(b), 61 YALE L.J. 76, 79-80 (1952).

172. 7 MOORE T 60.33 , at 512-13. See Chas. Pfizer \& Co. v. Davis-Edwards Pharmacal Corp., 385 F.2d 533 (2d Cir. 1967); Hawkins v. Lindsley, 327 F.2d 356, 359 (2d Cir. 1964); Martina Theater Corp. v. Schine Chain Theaters, Inc., 278 F.2d 798 (2d Cir. 1960); England v. Doyle, 281 F.2d 304 (9th Cir. 1960).

173. See Comment, supra note 111, at 42, citing Moore \& Rogers 692 n.268. In Mas v. Coca-Cola Co., 163 F.2d 505, 507-08 (4th Cir. 1947), the court denied relief on the ground that plaintiff as well as defendant had used fraudulent testimony and documents before the Patent Office, stating that the clean hands doctrine was for protection of the court, not the parties. Logically, then, where the other party and not the claimant has been guilty of some fraud, relief should be granted for protection of the court and the claimant. See also Precision Instrument Mfg. Co. v. Automotive Maintenance Mach. Co., 324 U.S. 806 (1945). In Conerly v. Flower, 410 F.2d 941 (8th Cir. 1969), the defendant misrepresented his liability insurance coverage to plaintiff. Plaintiff, during the course of the trial, agreed to settle for that amount, but both parties and the trial judge also agreed to submit the case to the jury. The jury found for plaimtiff and awarded double the settlement amount, but pursuant to the agreement the judge entered a verdict for the lesser amount. The court on appeal from a subdivision (3) motion characterized the fraud as fraud upon the court. It is difficult to distinguish this case from perjury cases, because plaintiff should clearly have been as diligent in verifying the correct liability coverage in defendant's policy as the victim of perjury in ferreting out his opponent's perjury.

174. See text accompanying note 162 supra. An example of difficulties in using a confused scheme of labeled remedies, which blurs the meaning of such labels in the process, is Bolden v. Sloss-Sheffield Steel \& Iron Co., 110 So. 574 (Ala. 1926), noted in Case Note, 12 CoRNeLr L.Q. 385 (1927). Bolden held that where the defendant claimed falsely that she was the wife of a deceased employee and thereby procured a judgment awarding her workman's compensation benefits, the plaintiff company could have such award vacated for "fraud upon the court as well as the opposing party." 
zation cases, which present a different context for "fraud upon the court" grounds. In Knauer v. United States, ${ }^{175}$ the Supreme Court held that a false oath of allegiance was a "fraud perpetrated on the naturalization court."176 Although perjury is intrinsic fraud and therefore application of Throckmorton would seemingly deny relief in a proceeding to cancel naturalization, the Court argued Throckmorton did not apply because the oath was not in issue. ${ }^{177}$ The Court unnecessarily confused the grounds for relief. The oath of allegiance was in fact the issue, but it was not an issue in a truly adversary proceeding. Furthermore, resort to rule 60(b) was unnecessary since relief was available by statute. ${ }^{178}$ In Lim Kwock Soon v. Brownell, ${ }^{179}$ the Fifth Circuit held that perjury relating to matters other than the oathmatters clearly in issue-was a ground to vacate an eight-year-old naturalization order "to correct the fraud perpetrated upon the courts." 180 If this fraud can be distinguished from the normal case of perjury, it is not because the court has been defiled, but rather because public policy considerations apply, such as the desire to protect the nation from undesirable aliens. ${ }^{181}$ Thus, fraud upon the court embraces a wider scope of fraud than that directed only against public organs of justice; it may in appropriate circumstances extend to a case where injury to the public is primarily and extraordinarily involved. However, there is no reason to believe it includes all forms of fraud.

The court reasoned that this was more than perjury "per se." Id. at 575. On rehearing, this holding was sustamed, but the court shifted its reasoning from fraud upon the court and granted relief for perjury by distinguishing other cases of perjury where relief is denied on the grounds that (1) the facts here did not relate to "alleged transactions between the parties" and (2) the claimed husband-wife relationship is one "peculiarly within the knowledge of the claimant ...." Id. at 580. In effect, the court was correctly arguing the equities of the case with terms ill-fitted to the issue, as the dissent on rehearing correctly noted. Id. at 582. Fraud of this sort can hardly be said to corrupt the judicial process in the same way that fraud by an officer of the court, or by the court itself, would. Cf. Menashe v. Sutton, 90 F. Supp. 531 (S.D.N.Y. 1950).

175. 328 U.S. 654 (1945).

176. Id. at $670-71$.

177. "The oath being the final step, no evidence is heard at that time. It comes after the matters in issue have been resolved in favor of the apphicant . . . " Id. at 671.

178. Act of Oct. 14, 1940, ch. $876, \S 338(\mathrm{a}), 54$ Stat. 1158 (now covered by 8 U.S.C.A. $\S 1451(\mathrm{a}))$; cf. U.S. CoNST. art. I, $\S 8$.

179. 369 F.2d 808 (5th Cir. 1966); see Note, Federal Rules 52(a) and 60(b)-A Chinese Puzzle, 21 Sw. L.J. 339 (1967).

180. 369 F.2d at 809 . For the earlier history of this case see Lim Kwock Soon v. Brownell, 143 F. Supp. 388 (S.D. Tex. 1956) and Lim Kwock Soon v. Brownell, 253 F. Supp. 963 (S.D. Tex. 1966).

181. This is the other half of the Hazel-Atlas rationale: "issues of great moment to the public." $C f$. Precision Instruments Mfg. Co. v. Automotive Maintenance Mach. Co., 324 U.S. 806, 816 (1945) (public importance of patent monopoly); Bros, Inc. v. W.E. Grace Mfg. Co., 320 F.2d 594, 608 (5th Cir. 1963) (same). 
III

The Relationship of the "ANy Other Reason" Clause TO OTHER GROUNDS FOR MOTION UNDER RULE 60(b)

An article that greatly influenced the 1946 amendments to rule 60(b) states:

[I] $\mathrm{t}$ is productive of harsh and inequitable results to enumerate exclusive situations when relief can be afforded by motion; and when this is done, courts will invent solne means of escape as by the doctrine of inherent power, or the doctrine that the term of the court gives power. ${ }^{182}$

This admonition may have prompted the Advisory Committee to add as grounds for relief the "any other reason" clause [subdivision (6)]. The addition of subdivision (6) did not, however, achieve the objective of eliminating the consequences of exclusive enumeration, because most courts interpreted the subdivision as exclusive of other grounds for relief and thereby rendered it practically ineffective. Soine courts, though, continued to invent means of escape from harsh and inequitable results.

The United States Supreme Court first applied and interpreted rule $60(\mathrm{~b})(6)$ in Klapprott $v$. United States. ${ }^{183}$ Klapprott, a naturalized citizen, had had his citizenship revoked by default judgment. Five years later he petitioned the court to set aside the judgment, alleging that 10 days before the judgment, and while in poor health, he had been imprisoned by federal authorities without money or legal assistance and charged with conspiring to violate the Selective Service Act. He alleged further that an F.B.I. agent did not deliver a certain letter requesting legal assistance as he had promised; that an attorney representing him on the Selective Service charge had failed to appear in the denaturalization proceedings as promised; and that he spent the next four years in various federal prisons until the authorities dismissed the conspiracy charge and readied him for deportation. Justice Black's opinion for the Court, while suggesting that the judgment was void for various reasons, ${ }^{184}$ argued that Klapprott had shown "an extraordinary situation which cannot fairly or logically be classified as mere 'neglect' on his part" and that his case also came under the "any other reason" clause because

[i]n simple English, the language of the "other reasons" clause, for all reasons except the five particularly specified, vests power

182. Moore \& Rogers 688. The 1946 amendments adopted nearly every criticism and proposal of these authors.

183. 335 U.S. 601, modified, 336 U.S. 942 (1949).

184. Id. at 609-13. 
in courts adequate to enable them to vacate judgments whenever such action is appropriate to accomplish justice. ${ }^{185}$

The two requirements for application of the "any other reason" clause thus appeared to be, first, the appearance of a reason other than one of the first five; and, second, the existence of ample justification for that reason. The two dissenters found relief barred by the one-year limitation on relief for "neglect" in subdivision (1) and for "other misconduct of the adverse party" in subdivision (3). They accurately predicted that the difficult future issue would be what must be done when relief appeared justified, but not for an "other reason."

The initial question is whether an exclusive interpretation-that is, that subdivision (6) is unavailable when the grounds for relief fall within the other subdivisions-is correct. Both the majority and the minority in Klapprott thought so in principle. Such was the stated intent of the draftsinen; ${ }^{186}$ and, it has been argued that any other reading of the rule's language would render the term "other" meaningless. ${ }^{187}$ Cases have frequently repeated this mutual-exclusiveness interpretation. ${ }^{188}$

The difficulty of such interpretation is that every conceivable ground for relief arguably comes within the first three subdivisions so that subdivision (6) would be superfluous. Therefore, whatever the stated intent of the drafters of the "any other reason" clause may be, it is more reasonable to suppose it means other special reasons of such a nature that, although the facts fit other subdivisions, they also compel the court to allow relief for equitable reasons. ${ }^{189}$ Subdivision (6)

185. Id. at 614-15. Cf. Ackermann v. United States, 340 U.S. 193, 202 (1950), wherein Justice Black, dissenting, modified his views. See text accompanying note 196 infra.

186. See 1954 Draft 55.

187. Klapprott v. United States, 335 U.S. 601, 609 (1949) (Reed, J., dissenting), modified, 336 U.S. 942; cf. 7 MOORE II 60.27[1], at 295-96.

188. E.g., Ackermann v. United States, 340 U.S. 193, 202 (1950); United States v. Erdoss, 440 F.2d 1221, 1223 (2d Cir. 1971); Rinieri v. News Syndicate Co., 385 F.2d 818, 822 (2d Cir. 1967); Boehm v. Office of Alien Property, 344 F.2d 194, 195 (D.C. Cir. 1965); Radack v. Norwegian America Line Agency, Inc., 318 F.2d 538, 542 (2d Cir. 1963); United States v. Karahalias, 205 F.2d 331, 335 (2d Cir. 1953); Zurini v. United States, 189 F.2d 722, 726 (8th Cir. 1951); Price v. United Mine Workers, 35 F.R.D. 27, 28 (E.D. Ky. 1963), aff'd, 335 F.2d 958 (1964); Federal Deposit Ins. Corp. v. Alker, 30 F.R.D. 527, 529, 532 (E.D. Pa. 1962); Davis v. Wadsworth Constr. Co., 27 F.R.D. 1, 2 (E.D. Pa. 1961); Mach v. Pennsylvania R.R., 198 F. Supp. 473, 474 (W.D. Pa. 1961); Lucas v. City of Junean, 20 F.R.D. 407, 410 (D. Alas. 1957).

189. Cf. Note, supra note 45, at 84; 7 MOORE If 60.27[1], at 293-94. Rule 6(b) exenupts rule $60(\mathrm{~b})$ from time enlargement "except to the extent and under the conditions stated in [it]," so it can be argued that the suggested interpretation of subdivision (6) is the "extent" and "condition" for enlargement. But see Rhodes v. Houston, 258 F. Supp. 546, 557-58 (D. Neb. 1966). 
should apply when there are any other equitable reasons in addition to those enumerated, as well as when there are reasons none of which come within the other subdivisions. It is arguable that this is the test which was actually applied in Klapprott. ${ }^{190}$ The facts were said to show more than "mere 'neglect' on his part,"101 yet it is accepted law that more than "mere" neglect is required for relief even under subdivision (1). ${ }^{192}$ Klapprott had apparently relied on an F.B.I. agent to deliver a letter requesting legal assistance and on his attorney to appear at the denaturalization hearing, and sucl a frustration of expectation has repeatedly been held in other cases to be at best only a subdivision (1) ground for relief. ${ }^{103}$ Thus, the decision that relief was warranted was not grounded on any exclusiveness of Klapprott's situation from those covered in the first three subdivisions of rule 60(b).

Klapprott required the reason to be "extraordinary" in order to warrant relief. This gives meaning to the requirement that the "other reason" justify relief. What is extraordinary and therefore justifies relief, lowever, is not necessarily exclusive of the other grounds. ${ }^{194}$ This has led many courts to ignore the exclusiveness rule, either expressly or in result. ${ }^{195}$ And regardless of Justice Black's language in

190. In Patterson v. Keeny, 165 Cal. 465, 132 P. 1043 (1913), similar facts were held to constitute excusable neglect.

191. 335 U.S. at 613.

192. Rule 60(b)(1) requires "excusable neglect"; see Cucurillo v. Schulte, Bruns Schiff GmbH, 324 F.2d 234 (2d Cir. 1963) (neglect must be excusable); Greenspahn v. Joseph E. Seagram \& Sons, Inc., 186 F.2d 616, 619 (2d Cir. 1951) (cannot be gross neglect). See generally 7 MOoRE $\llbracket 60.22[2]$, at 235 and cases cited nn.22-25. The Fifth Circuit, in addition to adopting Justice Black's Ackermann dissent that subdivisions (1), (2), (3), and (6) are not mutually exclusive, has applied subdivision (6) to a case consisting of "more than mere allegations of excusable neglect." Minier v. United States, 405 F.2d 245, 248-49 (5th Cir. 1968).

193. Ackermann v. United States, 340 U.S. 193, 198 (1950) (petitioner bound by reliance on a stranger); Link v. Wabash R.R., 370 U.S. 626, 633-34 (1962) (petitioner bound by voluntary choice of attorney); Stevens v. Stoumen, 32 F.R.D. 385, 387 (E.D. Pa. 1963); Mach v. Pennsylvania R.R., 198 F. Supp. 473, 474 (W.D. Pa. 1961). But see Minier v. United States, 405 F.2d 245 (5th Cir. 1968); L.P. Steuart, Inc. v. Matthews, 329 F.2d 234, 235 (D.C. Cir. 1964); United States v. Williams, 109 F. Supp. 456, 462 (W.D. Ark. 1952); Fleming v. Mante, 10 F.R.D. 391, 392 (N.D. Ohio 1950); United States v. Miller, 9 F.R.D. 506, 509 (M.D. Pa. 1949).

194. See United States v. Karahalias, 205 F.2d 331, 333 (2d Cir. 1953).

195. In United States v. Karahalias, 205 F.2d 331 (2d Cir. 1953), a naturalized Greek was given relief from a 17 -year-old default judgment cancelling his naturalization certificate, although he liad actual notice of the proceeding and freely chose to stay in Greece rather than leave his sick wife and children. Finding the petitioner's situation one of "extreme hardship" and technically within subdivision (1), the court said, "In short-to put it quite baldly—we read the subsection [(6)] as giving the court a discretionary dispensing power over the limitation inposed by the Rule itself on subsections (1), (2) and (3)." Id. at 333. Faced with the exclusiveness argument on petition for rehearing, the Second Circuit merely found that it had made an error in its 
Klapprott, he also apparently ignored this rule in his dissent in Ackermann, wherein he argued that "the draftsmen of the rule did not in-

finding of neglect-that as in Klapprott, Karahahas' inaction "resulted from forcible obstacles imposed upon his defense," not neglect. Id. at 335. See $3 \mathrm{~W}$. Barron \& A. HolTZOFF, supra note $124, \S 1330$, at 42 . This approach was criticized in McKinney v. Boyle, 404 F.2d 632, 634 (9th Cir.), cert. denied, 394 U.S. 492 (1968), rehearing denied, 395 U.S. 941 (1969) as "a semantic tour-de-force." Some courts refuse to adhere to rigid conceptualism. In Stevens v. Stoumen, 32 F.R.D. 385, 387 (E.D. Pa. 1963), the court held that in exceptional circumstances excusable neglect could be treated as within "any other reason," relying on Karahalias despite the latter's shift in basis on rehearing. Cf. Pierce Oil Corp. v. United States, 9 F.R.D. 619, 621 (E.D. Va. 1949). In L.P. Steuart, Inc. v. Matthews, 329 F.2d 234, 235 (D.C. Cir. 1964), cert. denied, 379 U.S. 824 (1964), the court went so far as to find the gross and inexcusable neglect of the movant's attorney enough under the circumstances to apply subdivision (6). The Fourth Circuit, in United States v. Cato Bros., Inc., 273 F.2d 153, 157 (4th Cir. 1959), held that the principle of ejusdem generis applied to all subdivisions so as to distinguish subdivision (6) from earlier subdivisions on general equitable principles. The court in Fleming v. Mante, 10 F.R.D. 391, 392 (N.D. Ohio, 1950), after listing equities in favor of a movant for rehef, said that though three years had passed since the judgment, "it is never too late to set aside an unjust judgment." See Loucke v. Umited States, 21 F.R.D. 305, 310 (S.D.N.Y. 1957). The Fifth Circuit has quite freely, although not consistently, registered its dissent from the exclusiveness doctrine, beginning with Bros, Inc. v. W.E. Grace Mfg. Co., 320 F.2d 594, 608 (5th Cir. 1963), where it argued that subdivisions (6) and (3) gave relief for similar grounds, and that "the conduct is to be tested by what it really is" so that a just disposition can be rendered. In re Casco Chem. Co., 335 F.2d 645, 651 n.18 (5th Cir. 1964), added that subdivision (6) "is, and is meant to be, flexible, and in its operative application relief may be broadened by virtue of grounds (1), (2), (3)." Laguna Royalty Co. v. Marsh, 350 F.2d 817, 823 (5th Cir. 1965), found that "[t]he rule is broadly phrased and many of the itemized grounds are overlapping, freeing Courts to do justice in hard cases. . . ." In Transit Cas. Co. v. Security Trust Co., 441 F.2d 788, 792 (5th Cir. 1971), the court seemingly repudiated the W.E. Grace doctrine, relying on the strict mutually-exclusive stance of the Second Circuit. E.g., Uinited States v. Erdoss, 440 F.2d 1221, 1223 (2d Cir. 1971); Rinieri v. News Syndicate Co., 385 F.2d 818, 822 (2d Cir. 1967). But relief was not warranted and the court approved of the district court's search for other reasons to bring "plaintiffs within the broad equitable power of Rule $60(\mathrm{~b})(6)$, which could be invoked to prevent extreme hardship or mjustice." Id. at 792 . Other courts have reached results consonant only with an implied repudiation of the exclusiveness doctrine. One granted rehef for the misconduct of an adverse party, which at most would appear to be grounds for relief under subdivision (3), three years after a default judgment. United States v. Miller, 9 F.R.D. 506, 508 (M.D. Pa. 1949). Another permitted a plaintiff to have a disinissal over a year old set aside where his attorney had mistakenly signed a stipulation of dismissal. Nelms v. Baltimore \& O.R.R., 11 F.R.D. 441 (N.D. Ohio 1951). See also King v. Mordowanec, 46 F.R.D. 474, 477-78 (R.I. 1969) (relief from attorney's gross neglect resulting in dismissal for failure to prosecute given nearly two years later under subdivision (6) ). The court in United States v. Williams, 109 F. Supp. 456, 462 (W.D. Ark. 1952), held that a three-year delay in setting aside a default judgment quieting title to land in the United States was not unreasonable. The defendant, an uneducated woman, who had to care for several children and work a farm herself when lier husband had deserted her, had relied on an attorney who failed to file an answer. While the facts failed to show more than neglect, the court stressed that the United States had given no consideration for the land and had expended no money on it while the defendant had fanned it and kept it im repair. In a doubtful 
tend that those specified grounds should prevent the granting of similar relief in other situations where fairness might require it."100 Even when the exclusiveness doctrine is accepted and the courts deny relief, there are usually sound grounds for the denial. ${ }^{107}$ In borderline cases, however, where courts have denied relief, the result inight well have differed had the court applied a inore liberal doctrine. ${ }^{108}$

\section{IV}

\section{Proposals For Modifying Rule 60(b)}

Before revising rule 60(b) it is necessary to understand what it is the Federal Rules attempt to do. One writer has explained that the recent amendments

continue a process of transition from legal formulas toward adaptation to the practicalities of the various factual situations involved. This process .... attempt[s] to eliminate many of the legalistic

case of even fraud or neglect, the court in Byron v. Bleakely Transp. Co., 43 F.R.D. 413 (S.D.N.Y. 1967) allowed the reopening of a default judgment over a year later. The defendant corporation never received notice of the action because it had neglected to notify the Secretary of State's office of its new address for service of process. The facts appealing to the court were those showing the plaintiff's deceptive actions. The plaintiff filed suit one day before the statute of limitation ran; she could have served the corporation personally since she knew its true address; and she waited 18 months to execute her judgment. Nevertheless, the court found the faets to constitute "other reasons."

196. 340 U.S. at 202-03. The Ackermanns were not as fortunate as Karahalias. While in the custody of their Alien Control Officer, they decided to forgo appeal from their denaturalization judgnient because an appeal would cost them their only asset-a $\$ 2,500$ house-and because that officer advised them that they would regain their freedoin after the war. Five years later, the Court held that the Ackermanns" "free choice" not to appeal, based upon a reliance on the officer's advice that was not "justifiable," was insufficient to evade subdivision (1) and its one-year time limit. Keilbar, Mrs. Ackermann's brother, appealed a judginent cancelling his naturalization; the judgment was reversed by stipulation with the United States Attorney. Justice Black argued that the Ackermanns were subjected to the "loss of all that makes life worth living" while possessing an admittedly perfect defense to the alleged fraud, and even though they were "foreign-born people, dependent on our laws for their safety and protection." Id. at 205. The majority distinguished Klapprott, finding here a trial on the merits, freedom of action, and available counsel.

197. See, e.g., Note, supra note 45, at 83; cf. 7 MoORE If 60.42, at 904 .

198. E.g., Ackermann v. Umited States, 340 U.S. 193 (1950); Costa v. Chapkins, 316 F.2d 541 (2d Cir. 1963) (16 months-attorney's illness and death resulted in disınissal for want of prosecution); Kathe v. United States, 284 F.2d 713 (9th Cir. 1960) (4 years-alleged out of court fraud by government which led to condemnation award held to be only within subdivision (1) or (3) ). See Zurini v. United States, 189 F.2d 722 (8th Cir. 1951); Rhodes v. Houston, 258 F. Supp. 546 (D. Neb.), cert. denied, 383 U.S. 971 (1966), 397 U.S. 1049 (1970); Price v. United Mine Workers, 35 F.R.D. 27 (E.D. Ky. 1963). Compare Weilbacker v. United States, 99 F. Supp. 109, 111 (S.D.N.Y. 1951) with Weilbacker v. J.H. Winchester \& Co., 197 F.2d 303, 305, 306 (2d Cir. 1952). Compare Patapoff v. Vollstedt's Inc., 267 F.2d 863, 865-66 (9th Cir. 1959) with Mach v. Pennsylvania R.R., 198 F. Supp. 473, 474 (W.D. Pa. 1961). 
but artificial restrictions that code practice perpetuated. The current amendments [articulate] ... rules that are designed to place before the court the actual substantive issue in the case with the minimum amount of formal procedural restrictions needed to ensure fair and orderly proceedings. ${ }^{\text {i99 }}$

While most writers would agree that a well-administered practical approach has more to offer than a formalistic one, several arguments oppose the proponent of change. Given the large number of federal district courts, difficulties and inconsistencies of a rule's application may be due not to the rule, but to "human fallibility."200 However, the previous discussions of relief from fraud and relief by motion indicate that the problem is more than simply one of vagaries in human judgment. Another argument is that the "profession should not be troubled with frequent small changes in a procedure basically sound."201 But this argument begs the question; the point of this Comment is that the profession is beset by a rule of conclusory labels the meanings and application of which are troubling. A third argument, that courts themselves should resolve these difficulties, ${ }^{202}$ is refuted by their past attempts. While it is not clear what the draftsmen's precise intent was in using such phrases as "independent action," "fraud upon the court," or "any other reason justifying relief," it is clear that present interpretations are often very confused and irrational. Finally, it is asserted that some states' heavy rehance on the Federal Rules argues against precipitous change, ${ }^{203}$ or at least that those states should "desirably have some share in any substantial change in policy."204 However, it is questionable whether a change of this type is really so precipitous as to cause problens, and, in any event, states could move slowly in response if they so chose. ${ }^{205}$

199. Cohn, The New Federal Rules of Civil Procedure, 54 Gzo. L.J. 1204, 1204 (1966).

200. Karr \& Groce, In the Matter of the Amendment Proposed By the Advisory Committee on Civil Rules to the Rules of Civil Procedure Dated October 24, 1961, 29 INs. C.J. 345, 346 (1962).

201. 1955 DRAFT 4. See Clark, The Proper Function of the Supreme Court's Federal Rules Committee, 28 A.B.A.J. 521, 521 (1942).

202. 1955 DRAFT 62-63; Clark, "Clarifying" Amendments to the Federal Rules?, 14 OHIo St. L.J. 241, 244 (1953); cf. 7 MOORE If 60.42, at 904.

203. E.g., Nordbye, Comments on Proposed Amendments to Rules of Civil Procedure, 18 F.R.D. 105, 105 (1956); 1955 DRAFT 3-4. See Wright, Amendments to the Federal Rules: The Function of Continuing Rules Committee, 7 VAND. L. REV. 521, 521 (1954). For a review of state practice as related to the Federal Rules, see generally, Clark, Special Problems in Drafting and Interpreting Procedural Codes and Rules, 3 VAND. L. ReV. 493, 496 n.8 (1950); Clark, supra note 202, at 242; Clark, The Federal Rules in State Practice, 23 RockY MT. L. Rev. 520 (1951); Clark, The Influence of Federal Procedural Reform, 13 LAW \& CoNTEMP. PRoB. 144 (1948).

204. Clark, supra note 202, at 244.

205. Id. at 250-51: "Much better to put up to the states the thinking about pro- 
The crux of the disagreement is not whether to forbid all change, but, rather, whether the courts or the Rules Committee should initiate it. One function of the Rules Committee, recognized by the Committee and commentators alike, is to codify and clarify case results and to "remove undesirable gloss" from the rules. ${ }^{206}$ But others have argued that the Committee should go even further and make improvements on existing practice. ${ }^{207}$

Courts have advanced numerous equitable considerations relevant to just determinations of rule 60(b) cases, which constitute the outlines of a modified rule. Decision on the merits is preferred, so that where there has been a default or dismissal with no decision on the merits, the court should resolve doubts in favor of relief. ${ }^{208}$ Under appropriate circumstances, relief should similarly be granted from consent judgments. ${ }^{209}$ The applicant for relief must show, of course, that his delay and neglect to use other remedial devices were justified. ${ }^{210} \mathrm{He}$

cedure whch new federal amendments must suggest than the sterility of literal acceptance of divinely ordered codes or rules perpetually to be maintained so far as their language is concerned."

206. Wright, supra note 203; cf. 1945 DRAFT 71, 73. See generally Clark \& Wright, The Judicial Counsel and the Rule-Making Power: A Dissent and a Protest, 1 SYRACUSE L. Rev. 346 (1950); Clark, Special Problems in Drafting and Interpreting Procedural Codes and Rules, 3 VAND. L. Rev. 493 (1950).

207. Wright, supra note 203 , at 523,555 . Some writers argue that the important advance has already been made by amended rule $60(\mathrm{~b})$ but that the courts are frustrating it. Note, Federal Rule 60(b), 61 YALE L.J. 76, 85-86; Comment, supra note 13, at 670,674 . The problem, however, is the same whether viewed as effectuating an advance already made by the rule or initiating another advance.

208. See Assniann v. Fleming, 159 F.2d 332, 336 (8th Cir. 1947). The default cases are Klapprott v. United States, 335 U.S. 601, 609, 615, modified, 336 U.S. 942 (1949); Butner v. Neustadter, 324 F.2d 783, 786-87 (9th Cir. 1963); Bridoux v. Eastern Airlines, Inc., 214 F.2d 207, 210 (D.C. Cir.), cert. denied, 348 U.S. 821 (1954); United States v. Karahalias, 205 F.2d 331, 334 (2d Cir. 1953); Tozer v. Charles A. Krause Milling Co., 189 F.2d 242, 245 (3d Cir. 1951); Ellington v. Milne, 14 F.R.D. 241, 242 (E.D.N.C. 1953); United States v. Miller, 9 F.R.D. 506, 508 (M.D. Pa. 1949); Ledwith v. Storkan, 2 F.R.D. 539, 541 (D. Neb. 1942). The dismissal cases are: Cavalliotis v. Salomon, 357 F.2d 157, 159 (2d Cir. 1966); Wojton v. Marks, 344 F.2d 222, 225 (7th Cir. 1965); L.P. Steuart, Inc. v. Matthews, 329 F.2d 234, 235 (D.C. Cir. 1964), cert. denied, 379 U.S. 824 (1965); Radack v. Norwegian America Line Agency, Inc., 318 F.2d 538, 542 (2d Cir. 1943); Pierre v. Bernuth, Lenıbcke Co., 20 F.R.D. 116, 117 (S.D.N.Y. 1956). This preference for judgment on the merits has a long history: "Any doubt that may exist should be resolved in favor of the application, to the end of securing a trial upon the merits." Jergins v. Schenck, 162 Cal. 747, 748, 124 P. 426, 426 (1912).

209. Fleming v. Huebsch Laundry Corp., 159 F.2d 581 (7th Cir. 1947); Assmann v. Fleming, 159 F.2d 332 (8th Cir. 1947); see Kathe v. United States, 284 F.2d 713, 715-16 (9th Cir. 1960); Delzona Corp. v. Sacks, 265 F.2d 157, 159 (3d Cir. 1959); United States v. 12,381 Acres of Land, 109 F. Supp. 279, 282 (D.N.M. 1953); 7 MOORE II 60.19, cases cited n.31 at 15 (Supp. 1970).

210. Rule $60(\mathrm{~b})$ relief is not a substitute for appeal. Ackermann v. United States, 340 U.S. 193, 198 (1950); In re Imperial "400" Nat"l, Inc., 391 F.2d 163, 172 
must also show his good faith ${ }^{211}$ and diligence, ${ }^{212}$ and that he was deprived of a good claim $^{213}$ or defense ${ }^{214}$ to his prejudice. ${ }^{215}$ Rule 60(b) gives no relief from free, informed choices. ${ }^{216}$ Courts also consider intervening rights, or prejudice to the other party, which prejudice sliould be discounted by the adversary's knowledge that the movant was unaware of all events until execution; ${ }^{217}$ prejudice can result from mere passage of time; ${ }^{218}$ and where rights or property liave vested, relief is normally not allowed. ${ }^{219}$ Although there clearly is no

(3d Cir. 1968); Wagner v. United States, 316 F.2d 871, 872 (2d Cir. 1963); Elgin Nat'1 Watch Co. v. Barrett, 213 F.2d 776, 779-80 (5th Cir. 1954); Geigel v. Sea Land Service, Inc., 44 F.R.D. 1, 2 (D.P.R. 1968). Neither is it a substitute for motion for new trial. Wojton v. Marks, 344 F.2d 222 (7th Cir. 1965); John E. Smith's Sons Co. v. Lattimer Foundry \& Mach. Co., 239 F.2d 815, 817-18 (3d Cir. 1956). But see Sternstem v. "Italia"-Societa Per Azioni Di Navigazione-Genoa, 275 F.2d 502 (2d Cir. 1960). And it is not a substitute for motion to amend a judgment. James Blackstone Memorial Ass'n v. Gulf, Mobile \& O.R.R., 28 F.R.D. 385, 386-87 (D. Conn. 1961).

211. Bridoux v. Eastern Airlines, Inc., 214 F.2d 207, 210 (D.C. Cir.), cert. denied, 348 U.S. 821 (1954).

212. E.g., Goldfine v. United States, 326 F.2d 456 (1st Cir. 1964) (two months after judgment not reasonable); Delzona Corp. v. Sacks, 265 F.2d 157, 159 (3d Cir. 1959); Yanow v. Weyerhaeuser S.S. Co., 274 F.2d 274, 281 (9th Cir. 1958), cert. denied, 362 U.S. 919 (1960); Rhodes v. Houston, 258 F. Supp. 546, 559 (D. Neb. 1966); Stevens v. Stoumen, 32 F.R.D. 385, 387 (E.D. Pa. 1963); Pierre v. Bernuth, Lembcke Co., 20 F.R.D. 116, 117 (S.D.N.Y. 1956).

213. Cavalliotis v. Salomon, 357 F.2d 157, 159 (2d Cir. 1966).

214. Consolidated Masonry \& Fireproofing, Inc. v. Wagman Constr. Corp., 383 F.2d 249, 251-52 (4th Cir. 1967); Butner v. Neustadter, 324 F.2d 783, 786 (9th Cir. 1963) (less showing required when judgment not on merits); Federal Deposit Ins. Corp. v. Alker, 234 F.2d 113, 117 (3d Cir. 1956); Tozer v. Charles A. Krause Milling Co., 189 F.2d 242, 244 (3d Cir. 1951); Federal Deposit Ins. Corp. v. Alker, 30 F.R.D. 527, 532 (E.D. Pa. 1962); United States v. Williams, 109 F. Supp. 456, 460-61 (W.D. Ark. 1952).

215. Radack v. Norwegian America Line Agency, Inc., 318 F.2d 538, 543 (2d Cir. 1963); Consolidated Gas \& Equip. Co. of America v. Carver, 257 F.2d 111, 115 (10th Cir. 1958); cf. Davis v. Wadsworth Constr. Co., 27 F.R.D. 3 (E.D. Pa. 1961).

216. E.g., Rinieri v. News Syndicate Co., 385 F.2d 818, 823 (2d Cir. 1967); Wojton v. Marks, 344 F.2d 222, 225 (7th Cir. 1965); Kathe v. United States, 284 F.2d 713, 716 (9th Cir. 1960); Von Wedel v. McGrath, 100 F. Supp. 434, 436 (D. N.J. 1951). But see Fleming v. Huebsch Laundry Corp., 159 F.2d 581, 584, 585 (7th Cir. 1947); Rarick v. United Steelworkers Union, 202 F. Supp. 902, 903-04 (W.D. Pa. 1962); Kable v. Amtorg Trading Corp., 13 F.R.D. 107, 108 (D.N.J. 1952).

217. Cavalliotis v. Salomon, 357 F.2d 157, 159 (2d Cir. 1966); Rooks v. American Brass Co., 263 F.2d 166, 168 (6th Cir. 1959); Byron v. Bleakley Transp. Co., 43 F.R.D. 413, 416 (S.D.N.Y. 1967); Pierre v. Bernuth, Lembcke Co., 20 F.R.D. 116, 117-18 (S.D.N.Y. 1956).

218. Rinieri v. News Syndicate Co., 385 F.2d 818, 823 (2d Cir. 1967); L.P. Steuart, Inc. v. Matthews, 329 F.2d 234, 238 (D.C. Cir. 1964) (dissenting opinion); Stevens v. Stoumen, 32 F.R.D. 385, 387 (E.D. Pa. 1963); Mach v. Pennsylvania R.R., 198 F. Supp. 473, 475 (W.D. Pa. 1961).

219. E.g., Hopkins v. Hebard, 235 U.S. 287, 291 (1914); West Virginia Oil \& Gas Co. v. George E. Breece Lumber Co., 213 F.2d 702, 707 (5th Cir. 1954); Lanning 
strict rule, courts should consider prejudice to adverse parties or third persons in light of the injury done to the applicant for relief and the burden on judicial administration of allowing new trials. Thus, the courts have taken account of the burden the judgment imposed upon the applicant. ${ }^{220}$ There has been a general relaxation of rules when relief is sought by a private litigant from a judgment in favor of the United States. ${ }^{221}$ This latter tendency is justified, especially in cases of denaturalization. ${ }^{222}$ The significance of citizenship to an individual makes it hard to understand how some courts can treat his application for rehief as if he were attacking a inere money judgment. ${ }^{22 a}$

Given the number of courts that either impliedly or expressly ignore a construction of rule 60(b) that requires mutually exclusive categories of relief with rigid time limits, and the consequent opportunity for inequality of application among the courts, sucli a construction slould be rejected. Rule 60(b) should be amended to give the federal courts greater flexibility and to clarify the procedures and grounds for relief by providing a statement in the rule of equitable factors that the court must consider.

v. National Sav. \& Trust Co., 2 F.R.D. 149, 150 (D.D.C. 1941); Shammas v. Shammas, 9 N.J. 321, 333, 88 A.2d 204, 210-11 (1952). But see Bridoux v. Eastern Airlines, Inc., 214 F.2d 207, 210 (D.C. Cir. 1954); Tozer v. Charles A. Krause Milling Co., 189 F.2d 242, 246 (3d Cir. 1951); In re Cremidas' Estate, 14 F.R.D. 15, 17 (D. Alas. 1953) (decedent's estate was still under administration so no property rights had vested yet).

220. E.g., Bridoux v. Eastern Airlines, Inc., 214 F.2d 207, 210 (D.C. Cir. 1954) ( $\$ 160,000$ is a "very large money judgment"); Tozer v. Cliarles A. Krause Milling Co., 189 F.2d 242, 245 (3d Cir. 1951) ( $\$ 14,000$ is a "large sum"); United States v. Miller, 9 F.R.D. 506, 509 (M.D. Pa. 1949) (\$24,780 "miglt well work complete disaster"); Henry v. Metropolitan Life Ins. Co., 3 F.R.D. 142, 144 (W.D. Va. 1942) (\$12,000 "is very substantial" and "[m]atters involving such sums should not be determined by default judgments if it can reasonably be avoided. ... .").

221. Fleming v. Huebsch Laundry Corp., 159 F.2d 581, 584 (7th Cir. 1947) ("We are dealing with a citizen and his government. The latter should not dcmand money unless the citizen owes it. . . G Good and loyal citizenry is not bred or developed by such conduct."); United States v. 12,381 Acres of Land, 109 F. Supp. 279, 282 (D.N.M. 1953) (liberal construction required in dealings between government and citizen "in order to prevent unfair and unjust trentment"); United States v. Williams, 109 F. Supp. 456, 462 (W.D. Ark. 1952) (vacated default judgment quieting title in government, finding that government lad given no consideration for the land nor lad it expended any money on it); Fleming v. Mante, 10 F.R.D. 391, 392 (N.D. Ohio 1950) (violation of rent control act); United States v. Miller, 9 F.R.D. 506, 508 (M.D. Pa. 1949) (violation of price regulations); see Weilbacher v. J.H. Winchester \& Co., 197 F.2d 303, 306 (2d Cir. 1952) (dissenting opinion).

222. E.g., Klapprott v. United States, 335 U.S. 601, 609 (1949): "It scems inconceivable that one could think it would work any injustice to the Government to measure the petitioner's rights by this amended rule ... where all he asks is a chance to try the denaturalization proceeding on its merits."

223. See, e.g., Ackermann v. United States, 340 U.S. 193 (1950); Zurini v. United States, 189 F.2d 722 (8th Cir. 1951); but cf. United States v. Karahalias, 205 F.2d 331, 334 (2d Cir. 1953); Trop v. Dulles, 356 U.S. 86 (1958). 
Any amendment to rule 60(b) should (1) abolish the extrinsicintrinsic distinction in the independent action, (2) clarify "fraud upon the court," and (3) release the courts from the one-year limitation for stated grounds for relief by providing that for generally stated equitable considerations the court in its sound discretion, with due regard for the various aims of finality, may give relief at any time. The 1946 amendment to rule 60(b) providing for relief from fraud "whether lieretofore denominated intrinsic or extrinsic" was certainly a step towards abolishing the extrinsic-intrinsic distinction. ${ }^{224}$ That same amendment also provided for longer time periods during which the court could consider motions for relief, and it expanded and clarified the grounds on which relief by motion could be had. Nevertheless, as the cases illustrate, the extrinsic-intrinsic distinction survived in the independent action; there were still rigid and unalterable time limitations for motions; and the "any other reason" clause was often restrictively interpreted to apply only to "extraordinary" reasons exclusive of those stated in the first three subdivisions.

The rationale for amendment of the fraud provision is that the court ought to be allowed to give equitable relief, for equitable considerations. Any amendment should reject the extremes of absolute limitations and absolute rights to rehef. ${ }^{25}$ If one accepts the threshold proposition that there can be no realistic distinction between intrinsic and extrinsic fraud, it follows that all fraud, in whatever court brought, and in whatever form presented, should be without limitation in time other than laclies. ${ }^{226}$ An exception would be "fraud upon the court," where not even laclies is a limitation on relief. A deceptively appealing alternative to the open-ended equitable approach is that the one-

224. See note 2 supra.

225. Several proposals in this vein have been made. Some writers suggest adoption of the rule stated in Marine Ins. Co. v. Hodgson, 11 U.S. (7 Cranch) 332, 336 (1813), that

[w]ithout attempting to draw any precise line to which courts of equity will advance, and which they cannot pass, in restraining parties froin availing themselves of judgments obtained at law, it may safely be said, that any fact which clearly proves it to be against conscience to execute a judgment, and of which the injured party could not have availed himself in a court of law; or of which he might have availed himself at law, but was prevented by fraud or accident, unmixed with any fault or negligence in himself or his agents, will justify [relief] . . . .

See Laun v. Kipp, 155 Wis. 347, 372-73, 145 N.W. 183, 192-93 (1914); Recent Decisions, 40 Mich. L. REv. 598, 599-600 (1942); cf. Comment, supra note 111, at 50-51. See also 3 W. Barron \& A. Holtzoff, supra note 124, \$ 1330, at 427; Moore \& Rogers 659; Comment, supra note 13, at 674-75.

226. But cf. Recent Decisions, 31 CALIF. L. Rev. 600, 604-05 (1943) (suggesting that if in present practice the distinction is difficult to make, perhaps a more rigid and precise definition of extrinsic fraud should be promulgated in the interests of uniformity). 
year limitation presently employed be tolled until the defrauded party knows, or should have known, of the fraud. ${ }^{227}$ But finality would truly be in danger under such a scheme; 228 after a period the claim would become stale, since evidence would be uncertain and intervening rights would be endangered. The rule could in fact becoine quite inequitable. There seem to be no grounds for a rule giving a party an absolute right to rehief without taking into account these other equitable considerations, even if he acts reasonably.

Similar considerations cover the remaining motions under rule 60(b). As in the case of fraud, the Advisory Committee itself has suggested that motions be "made within a reasonable time, and for reasons (1), (2), (3) and (6) not more than one year after the grounds therefor have accrued and are known to the moving party."220 This 1954 proposal recognized that the courts were ignoring the mutual-exclusiveness rule in the interest of justice, while showing due regard to the aims of finality, and this was an attempt to legitimate such an interpretation and to allow "a more flexible approach which looks to the reasonableness of the delay and the equities of the judgment creditor." ${ }^{230}$ Reaction to this proposal was mixed, ${ }^{231}$ and in 1955 the Committee excluded the amendment, stating only that "the courts seem to have been resolving this problem in a flexible and satisfactory manner . . .."232 While this proposal threatens finality by considering only the moving party's knowledge, a resurrection of this proposal with some revision to include other important equitable considerations is appropriate.

There is always present the general fear that to do away with rigid time limits would unsettle judgments to an intolerable degree, but this fear is groundless. Where courts have been allowed a wide discretion, as in Wisconsin or in the traditional cases of extrinsic fraud, they have been quite sufficiently concerned with the aims of finality. ${ }^{233}$ However, finality will be seriously compromised unless the courts are given more than just a general directive for the exercise of their power. Any amendment increasing the courts' flexibility and discretion must also contain some guidelines for practice.

227. 1954 DRAfT 54. See also Recent Decisions, 23 CaLIF. L. Rev, 217, 218 (1935).

228. See 7 MOORE $\int 60.42$, at 905-06.

229. 1954 DRAFT 54.

230. Id. 54-55.

231. Compare Wright, supra note 203 , at $548-49$, and Nordbye, supra note 203 , at 119-20 with 7 MOORE If 60.42, at 905-07.

232. 1955 DRAFT 62-63.

233. 1954 Draft 56. See also Comment, supra note 13, at 675; Note, Federal Rule 60(b), 61 YALE L.J. 76, 86. But see 7 MoORE $\int 60.16[5]$, at 89. 
In order to avoid the traps of technical formalism and unguided discretion, a functional approach should be taken. ${ }^{234}$ Courts should be directed to consider the real facts and equities rather than mere labels. Such an approach was successfully accomplished in other amendments, ${ }^{235}$ and there are no cogent reasons for a contrary expectation in a similar treatment of rule 60(b). The "just terms" clause ${ }^{236}$ would be preserved in the amended rule and courts should make more extensive and effective use of it. Neither should the reasons as now stated be clianged. They do, for the most part, sufficiently cover grounds for which rehief should be granted.

Therefore, this Comment proposes the following amendment to rule $60(\mathrm{~b})^{237}$ (provisions deleted from present rule $60(\mathrm{~b})$ are indicated in brackets; provisions added by the proposed amendment are indicated in italics):

On motion and upon such terms as are just, the court may relieve a party or his legal representative from a fimal judgment, order, or proceeding for the following reasons: (1) mistake, inadvertence, surprise, or excusable neglect; (2) newly discovered evidence which by due diligence could not have been discovered in time to move for a new trial under Rule 59 (b); (3) fraud [(whether heretofore

234. Cf. Clark, Special Problems in Drafting and Interpreting Procedural Codes and Rules, 3 VAND. L. REv. 493, 499, 501 (1956).

235. See Fed. R. Civ. P. 19 ("Joinder Of Persons Needed For Just Adjudication"). For a general discussion of the prior rule and how it is different from the new rule, see 3A MOORE II 19.01, at 2105-15. The rule was amended in 1966 to provide factors that the court ought to consider in determining whether a party is "indispensable" to an action. The new rule states more clearly the prior practice rather than departure from prior law. 3A J. Moore, II 19.01[5.-4], at 1213, If 19.05, at 2206, If 19.07-1 [0]-[1], at 2252-53; Recent Changes in the Federal Rules of Procedure, 42 F.R.D. 552, 562 (1966); 2 W. BARRON \& A. HolTZOFF, supra note 124, § 512, at 5-6 (1967 Supp.). But see Cohn, supra note 199 , at 1210 . The new approach is uniformly applauded for its emphasis on articulating the bases of any conclusion.

236. Fed. R. Crv. P. 60(b): "On motion and upon such terms as are just ..." the courts may give specified relief. For example, the court has required that the defendant pay into court the money or a reasonable substitute therefor, in order to vacate a default judgment [Thorpe v. Thorpe, 364 F.2d 692, 694 (D.C. Cir. 1966)]; that the default defendant pay the plaintiff's counsel taxable costs to date, deposition costs, telephone costs, and attorney fees to date [Trueblood v. Grayson Shops of Tennessee, Inc., 32 F.R.D. 190, 195 (E.D. Va. 1963)]; that according to the facts the court may require a greater or lesser showing for rehef by the default defendant [Id. at 196]; that the dismissed plaintiff pay $\$ 250$ for the defendant's expenses and inconvemence [Robins v. Pitcairn, 3 Fed. Rules Serv. $\$ 60 b .21$, at 604 (N.D. Ill. 1940)]; that the defaulting defendant be taxed costs for appeal [Tozer v. Charles A. Krause Milling Co., 189 F.2d 242, 246 (3d Cir. 1951)]; that the defaulting defendant's counter-claim be dismissed [Bridoux v. Eastern Airlines, Inc., 214 F.2d 207, 210 (D.C. Cir. 1954)]; that the dismissed plaintiff return sums received [Weilbacher v. Umited States, 99 F. Supp. 109, 111 (S.D.N.Y. 1951)].

237. The rule is written in full. Note that rule $6(\mathrm{~b})$, which omits extension of time limits in present rule $60(\mathrm{~b})$, would likewise have to be amended; this can easily be accomplished by omitting 60 (b) from the listed subject to the exception. 
denominated intrinsic or extrinsic)], misrepresentation, or other misconduct of an adverse party; (4) the judgment is void; (5) the judgment has been satisfied, released, or discharged, or a prior judgment upon which it is based has been reversed or otherwise vacated, or it is no longer equitable that the judgment should have prospective application; or (6) any other reason justifying relief from the operation of the judgment. [The motion shall be made within a reasonable time, and for reasons (1), (2), and (3) not more than one year after the judgment, order, or proceeding was entered or taken.] A motion under this subdivision (b) does not affect the finality of a judgment or suspend its operation. This rule does not limit the power of a court to entertain an independent action to relieve a party from a judginent, order or proceeding, or to grant relief to a defendant not actually personally notified as provided in Title 28 , U.S.C., $\S 1655$, or to set aside a judgment for fraud upon the court. The distinction between extrinsic and intrinsic fraud for all purposes is abolished. Relief by motion or independent action may be allowed within a reasonable time, and not more than one year after the judgment, order, or proceeding was entered or taken. However, the court may in its discretion determine that relief is justified at any time, upon consideration of the following factors: (1) the extent to which the party has received a full and a fair trial of the issues; (2) the degree of the party's own negligence or fault, his diligence in seeking relief, the nature and quality of his claim or defense, and the detriment to the party if relief is denied; (3) the degree of the other party's fault or wrongdoing, and the nature and quality of his claim or defense; (4) a preference that decision be on the merits, but with due regard to the rights of the other party and third persons and the requirement that judgments be final; (5) the degree to which detriment to the other party or to third persons may be reduced by imposition of just terms on the party seeking relief, including posting of bond to cover the other party's costs should the moving party fail to show reasons justifying relief. Relief for fraud upon the court may be allowed at any time, but the court shall consider the extent to which the fraud impaired judicial impartiality, the extent to which the fraud affects the public interest, and the extent to which rights of third persons may be adversely affected if relief is granted. Writs of coram nobis, coram vobis, audita querela, and bills of review and bills in the nature of a bill of review, are abolished, and the procedure for obtaining any relief from a judgment shall be by notion as prescribed in these rules or by an independent action.

\section{CONCLUSION}

This Comment has analyzed the evolution of procedures for relief from judgments under rule $60(\mathrm{~b})$ and suggested proposals for 
amendment. The rule is today an efficient and smoothly working rule. However, there are two major areas of difficulty: relief from fraud and relief by motion under subdivisions (1), (2), (3), and (6). These difficulties are rooted in the confused and illogical procedures for relief from fraud, the continuance of the extrinsic-intrinsic distinction in independent actions, and the general desire of many courts to dispose equitably of claims for relief in the face of a rule that at times makes equitable results secondary to formal symmetry.

Resolution of these problems requires a clarification of the practice under the rule and a reformulation of the rule itself. Emphasis should be on laying out the function of the court and on providing equitable guidelines. Thus, relief from fraud should be conditioned on a consideration of the circumstances of the case and not on a predetermined label with rigid time limits. Fraud upon the court sliould be expressly limited to certain circumstances relating to impairment of judicial impartiality. Relief for other reasons depends similarly on equitable considerations in light of the particular facts of the case and not on whether an arbitrary time period has passed or on whether the "other reason" is inutually exclusive from the stated reasons. Both the aims of finality and individual justice can be accommodated by such an amendment, and the federal courts are experienced in operating within such a flexible system. The modifications suggested would clarify the procedures for rehef, making them simpler to apply and more just in result.

Thomas D. Clark 